\title{
Geochemistry of Minor
}

\section{Elements in Coals of the}

Northern Great Plains

\section{Coal Province}

GEOLOGICAL SURVEY BULLETIN 11117 -A 



\section{Geochemistry of Minor Elements in Coals of the Northern Great Plains Coal Province}

By PETER ZUBOVIC, TAISIA STADNICHENKO, and NOLA B. SHEFFEY MINOR ELEMENTS IN AMERICAN COALS GE OLOGICAL S U R V E Y B U L L E T I N 1117-A

$A$ study of 15 minor elements in some of the coals of Montana, North Dakota, and Wyoming

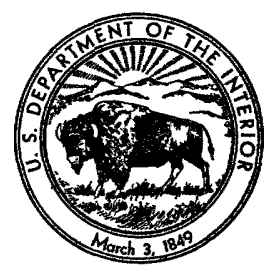




\section{UNITED STATES DEPARTMENT OF THE INTERIOR}

STEWART L. UDALL, Secretary

\section{GEOLOGICAL SURVEY}

Thomas B. Nolan, Director 


\section{CONTENTS}

\begin{tabular}{|c|c|}
\hline & \\
\hline & $A-1$ \\
\hline ion....................... & \\
\hline Purpose and scope & \\
\hline Location and fieldwork & \\
\hline wledgments & \\
\hline stigations_..... & \\
\hline sampled areas & \\
\hline of samples.- & \\
\hline 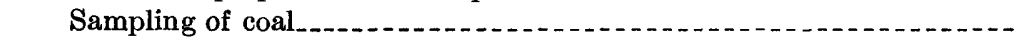 & \\
\hline (1- & \\
\hline oals & \\
\hline s' & \\
\hline ic analysis & \\
\hline Id limits of selection & \\
\hline acy & \\
\hline data_- & 2 \\
\hline - & 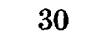 \\
\hline ements....................... & 3 \\
\hline hic constituents of coal & 3 \\
\hline lumnar samples of the coal beds....... & \\
\hline 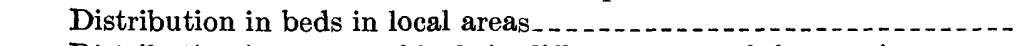 & \\
\hline different parts of the province..... & \\
\hline elation of the minor-element content of coal ash and possible source rock & \\
\hline $\begin{array}{l}\text { omparison of the average minor-element content of the coal with that of } \\
\text { living plants }\end{array}$ & \\
\hline ( & \\
\hline 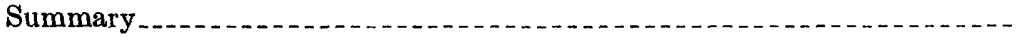 & \\
\hline d & \\
\hline
\end{tabular}

\section{ILLUSTRATIONS}

Plate 1. Distribution of the elements in coal beds of the northern Great Plains province.

Figure 1. Map showing geologic features discussed in this report. ........ A-6

2. Index map to the location of the coal samples......... 7

3. Comparison of the minor-element content of coal ash with the minor-element content of different rock types.......... 


\section{TABLES}

TABLE 1. Location and description of samples

2. Data on the compositing and flotation of samples........

3. Analytical data on the elements in the ash of the coal samples of the Northern Great Plains coal province

4. Average minor-element content in the ash of the coal beds..-

5. Average minor-element of the samples of coal beds and the special samples

6. Comparison of the minor-element content of ash of coals of this province and of West Virginia and the relation to their clarkes

7. Summary of data from tables $3,4,5$, and 6

8. Distribution of the elements in petrographic constituents of coal

9. Distribution of the elements in vertical sequences in coal beds

10. Areal distribution of the elements of groups of bed samples. Localities in figure $1 \mathrm{~b}$

11. Range of accumulation of copper, zinc, molybdenum, and nickel in parts of plants in mineralized areas

12. Comparison of the minor-element content of the coals of the Northern Great Plains province with that of some plants.--

13. Comparison of the minor-element content of kettle-bottom coals and coalified trees with the associated coal beds

14. Ratios of the minor-element content of the kettle-bottom coals and coalified trees to that in the associated beds......... 


\title{
MINOR ELEMENTS IN AMERICAN COALS
}

\section{IGEOCHEMISTRY OF MINOR ELEMENTS IN COALS OF THE NORTHERN GREAT PLAINS GOAL PROVINCE}

\author{
By Peter Zubovic, Taisia Stadnichenko, and Nola B. Sheffey
}

\begin{abstract}
The Northern Great Plains coal province encompasses an area in four northcentral States. A geochemical study has been made of the following 15 minor elements in the coals: boron, beryllium, titanium, vanadium, chromium, cobalt, nickel, copper, zinc, gallium, germanium, molybdenum, tin, yttrium, and lanthanum.

The coals that were studied range from Jurassic to Eocene. Data for 4 columnar samples of Jurassic coal, a single sample of Cretaceous coal, 20 channel or auger samples and 20 columnar samples of Paleocene coal, and 6 channel samples of Eocene coal are presented and evaluated in a series of tables: (a) individual analyses; (b) averages of the elements in ash of coal beds; (c) average in parts per million in coal beds; additional tables and figures utilizing parts of the data are used in the text as needed to illustrate points of discussion.

Pertinent aspects of the geochemistry of these elements in the coals are discussed. An analysis of some petrographic constituents of these coals shows that fusains contain appreciable quantities of the elements. This is in contrast with findings from other coal provinces of the United States where larger amounts of most of the elements are found in vitrains.

Within coal beds no systematic variation of the elements was found. However, a relation between some of the 15 elements and an influx of material into the developing swamp and the apparent lack of secondary redistribution or of accumulation indicate that the elements accumulated at the time of formation of the swamp.

A comparison of series of beds in stratigraphic columns does not indicate any secondary mineralization, such as by the leaching of overlying beds or by hydrothermal activity. The sampling, however, is not adequate for any positive conclusions. A comparison of the 15 minor elements in groups of beds in various parts of the province shows that beryllium, titanium, vanadium, cobalt, gallium, yttrium, and lanthanum have preferential distribution patterns in the basin; however, more sampling is needed for adequate comparisons of patterns.

A comparison of the minor-element content of these coal samples and of living plants shows that most of these elements can be accumulated by plants in the amounts found in the coal. Comparison of the minor-element contents of various rock types and the ashes of samples of coal of the Fort Union formation indicates that the minor-element suite of the coal ash is similar to that of silicic and intermediate rock types, which were the major source of sediments during the period
\end{abstract}


of coal deposition. This also indicates that the accumulation of the 15 minor elements in the coals was a syngenetic process.

The kettle-bottom coal and coalified trees that lie above the coal beds are discussed separately in this report because of the anomalous content of some of the elements in them The degree of enrichment in comparison with the coal beds with which they are associated is $\mathrm{Ge}>\mathrm{V}>\mathrm{Cr}>\mathrm{Ga}>\mathrm{Co}, \mathrm{Ni}, \mathrm{Y}>\mathrm{Mo}, \mathrm{Be}, \mathrm{Ti}, \mathrm{Sn}>\mathrm{Cu}>\mathrm{La}>\mathrm{B}$. Genetic relations of the kettle-bottom coals and coalified trees and of the coal beds, as well as stability constants of metallo-organic complexes, are used to explain the disparity of the element content of these special types of samples and the beds.

\section{INTRODUCTION}

\section{PURPOSE AND SCOPE}

This is the first report on the geochemistry of 15 minor elements in the coal regions of the United States. The purpose of this investigation is to achieve a better understanding of the geochemistry of these elements in coals, and to investigate the concentration of these elements in coals from an economic standpoint.

Data of the analyses of individual and composite samples of blocks of 25 columnar samples and 26 channel and auger samples of coals from Montana, North Dakota, and northeastern Wyoming are given in this report. The number of samples is somewhat small for a representative collection from an area containing our largest reserves of coal and lignite. However, the authors preferred to collect only unweathered columnar coal samples, so sampling was possible only in the mines in operation and accessible at the time the fieldwork was done. It is believed, nevertheless, that these data are adequate for an initial study of the coals of this province.

\section{LOCATION AND FIELDWORK}

The Northern Great Plains coal province encompasses an area in four north-central States: the western half of North Dakota, the northwestern part of South Dakota, the northeastern part of Wyoming, and the eastern and north-central parts of Montana. Subdivisions, regions, and fields mentioned in the text are shown in figure 1.

The fieldwork in the province was done in three trips. During the first of these, made by Taisia Stadnichenko in the fall of 1950, 7 columnar samples of coal were collected in North Dakota, 1 complete columnar sample and several selected blocks from another bed in Wyoming, and 5 columnar samples in Montana. On her second field trip 2 additional columnar samples were collected in Montana in 1953. In the fall of 1952, Peter Zubovic visited the western coal fields and collected 9 columnar samples in Montana.

In addition to samples collected by the authors, geologists of the U.S. Geological Survey submitted 26 channel and auger samples of coals and lignites collected in areas where they were working, as 
follows: G. S. Prichard, 10 samples from Richland County, Mont.; W. D. Johnson, 7 from Oliver County, N. Dak.; W. J. Mapel, Jr., 6 from the Lake de Smet area of Johnson County, Wyo.; W. T. Pecora, 3 from the Bearpaw Mountains area of Chouteau County, Mont. A detailed description of all samples is given in table 1.

\section{ACKNOWLEDGMENTS}

Study of the coal deposits of the Northern Great Plains coal province was greatly expedited by many individuals. The authors give their thanks for the cooperation of the mine owners, the superintendents, and the miners at those mines where samples were collected. In the U.S. Geological Survey we wish to thank H. I. Smith and his coworkers for providing information and assistance in the field. Thanks are extended to W. J. Mapel, Jr., W. D. Johnson, G. S. Prichard, and W. T. Pecora, for the samples that they submitted.

For earlier spectrographic analyses we thank K. J. Murata, H. J. Rose, Jr., Elizabeth L. Hufschmidt, R. S. Harner, and Janet D. Fletcher. In the coal laboratory J. H. Townsend and H. M. Cohen proved invaluable as assistants.

Many members of the Survey contributed immeasurably in discussions of geochemical problems, particularly K. J. Murata and Michael Fleischer.

\section{PREVIOUS INVESTIGATIONS}

The minor-element content of coal was first investigated by the U.S. Geological Survey in 1935, when Taisia Stadnichenko collected, prepared, and submitted for analysis 19 samples of ash from coal of the Lower Kittanning bed in western Pennsylvania. These samples were analyzed for germanium and several other elements by George Steiger, former chief chemist. A second suite of samples was processed similarly in 1942 .

Investigations of minor elements in coal came into prominence in the early and mid 1930's. This was largely due to the findings of Goldschmidt (1930) and Goldschmidt and Peters (1933) who reported unusual concentrations of germanium and other minor elements in several samples of European coal. Of particular interest were several analyses of samples from the Hartley coal bed in England, where 1.1 percent germanium in ash was reported. Morgan and Davies (1937) reported on the ashing of coal and the loss of germanium under certain conditions, and showed that some germanium was concentrated in flue dust. A method for recovering germanium from flue dusts of gas works was suggested; these flue dusts have since become a source of the element in England.

Interest in germanium as a semiconductor increased tremendously during and shortly after World War II, and, as a result, a search was 
begun for sources of this element. Because of the results of earlier work by Goldschmidt and other scientists, many organizations, public and private, began to look for this element in coals. In the United States the Eagle-Picher Co. was one of the first and most active in this line of research. The U.S. Geological Survey began a study of minor elements in American coal by Taisia Stadnichenko in 1948. Fieldwork and analytical work started immediately and has been carried on to the present. Although provincial and regional reports could not be prepared until analyses of coal samples collected from these areas were adequately completed, some topical papers have been published (Stadnichenko, Murata, and Axelrod, 1950; and Stadnichenko, Murata, Zubovic, and Hufschmidt, 1953): The last-mentioned publication is a report on the concentration of germanium in the ash of coals analyzed before the fall of 1952. It includes analyses of coal ash from the Northern Great Plains coal province.

Two publications resulting from the interest in the uranium content of lignite of North Dakota and South Dakota also present aspects of a part of this province. Breger, Deul, and Rubinstein (1955) made a detailed study of the concentration of uranium in a sample of lignite from South Dakota; Deul and Annell (1956) reported on the concentration of 27 minor elements, including germanium, in lignite from Bowman County, N. Dak., and Harding and Perkins Counties, S. Dak.

The literature on the occurrence of some elements in coal was summarized by Gibson and Selvig (1944), and on germanium by Fleischer and Harder (1946). Since Goldschmidt's pioneer work, a large number of investigators in many countries have reported on the association of germanium and other elements with coal. Among the more interesting and informative reports are the following:

Argentina: Lexow and Maneschi, 1950.

Australia: Cooke, 1938.

Belgium: Legraye and Coheur, 1944-45.

Canada: Fortescue, 1954; Hawley, 1955; Newmarch, 1953.

Czechoslovakia: Simek, 1940.

England: Aubrey, 1952, 1954, and 1955; Davidson and Ponsford, 1954; Forrest, Smith, and Ward, 1955; Horton and Aubrey, 1950; Jones and Miller, 1939; Morgan and Davies, 1937; Pitt and Fletcher, 1955; Powell, Lever, and Walpole, 1951; Reynolds, 1948 and 1950.

Germany: Otte, 1953.

India: Ganguly and Dutta, 1956; Iyer and Sundaram, 1955; Mukherjee, 1950; Mukherjee and Dutta, 1948, 1949, and 1950; Subrahmanyan and Nair, 1955.

Italy: Abbolito, 1942; Bertetti, 1954.

Japan: Asai, 1954; Asai and Inagaki, 1952; Dono, Yoshida, Aoki, Nakagawa, and Iga, 1951; Iwasaki and Ukimoto, 1942; Inagaki, 1951, 1952, 1953a, 1953b, and 1956; Inagaki and others, 1954; Oka, Kanno, Ayusawa, and Haga, 1955; Ono, Inada, and Kanno, 1955. 
New Zealand: Rafter, 1945; Wilson and Rothbaum, 1950.

Nigeria: Simpson, 1954.

Portugal: Brito, 1955a, 1955b.

South Africa: Kunstmann and Hammersma, 1955.

Spain: Lopez de Azcona and Puig, 1948.

Spitsbergen: Butler, 1953.

Union of Soviet Socialist Republics: Borovik and Ratynskiy, 1944; Itkina, 1948; Katchenkov, 1948, and 1952; Kostrikin, 1939; Miropolskii, 1939 and 1942; Nazarenko, 1937; Ratynskiy, 1945 and 1946; Shakhov and Efendi, 1946; Zilbermintz, 1935 and 1936; Zilbermintz and Rusanov, 1936.

United States: Breger, Deul, and Meyrowitz, 1955; Breger and Schopf, 1955; Headlee and Hunter, 1955; Machin and Witters, 1956; Schleicher and Hambleton, 1954.

In addition, the following investigations of minor elements of peat bogs are worth noting:

Finland: Salmi, 1950, 1954, and 1955.

United States: Cannon, 1955; Fiskel, Mourkides, and Gammon, 1956.

\section{DESCRIPTION OF THE SAMPLED AREAS}

This is a brief description of the areas of the Northern Great Plains coal province from which samples have been collected. Details of each of the samples analyzed are given in table 1. The geologic features are shown in figure 1 and index to the distribution of the samples is shown in figure 2. For more complete descriptions of the coal beds, and the geology and structure of the areas, Brant, 1943; Berryhill, Brown, and Taylor, 1950; and Combo, Brown, Pulver, and Taylor, 1949, and the references cited in these three publications may be consulted.

The coal-bearing formations of the province range from the Morrison of Jurassic age to the Wasatch of Eocene age. The Jurassic coals are found in the Great Falls and Lewistown fields of central Montana; the Cretaceous are found in the north-central region. The most prolific coal-accumulating swamps formed in Fort Union time, especially during the deposition of the Tongue River member of the Fort Union formation. Most of the coals of the Fort Union region and those of the Powder River region are of this age.

A unique characteristic of the coals of this province, with the possible exception of the coal from the Morrison formation, is the limited extent of the beds. Coal was deposited in small basins surrounded by non-coal-forming areas. As a result of this, beds are discontinuous, pinching out in relatively short distances, and their correlation in different parts of the basin is impossible. 


\section{$A-6$}

MINOR ELEMENTS IN AMERICAN COALS

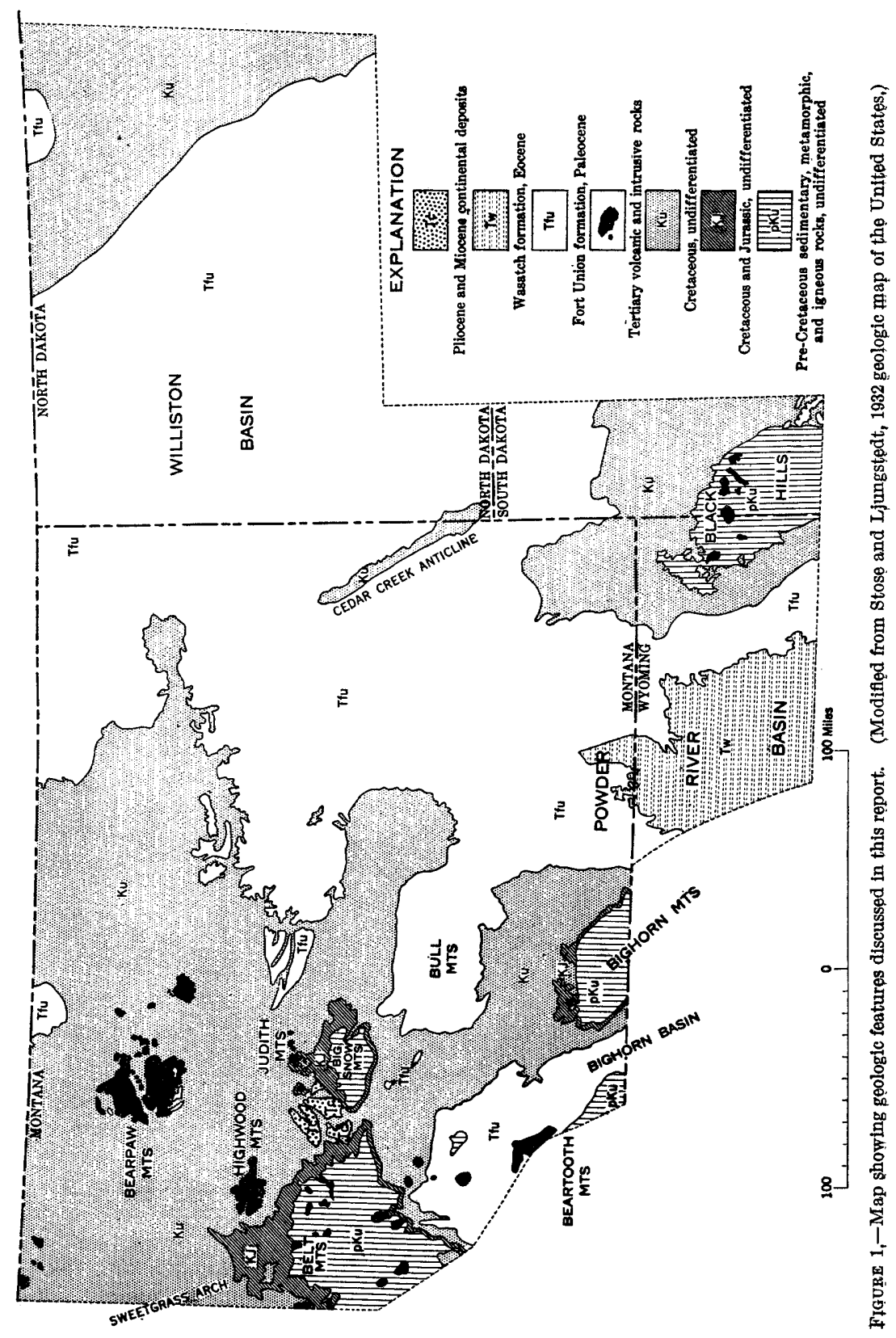




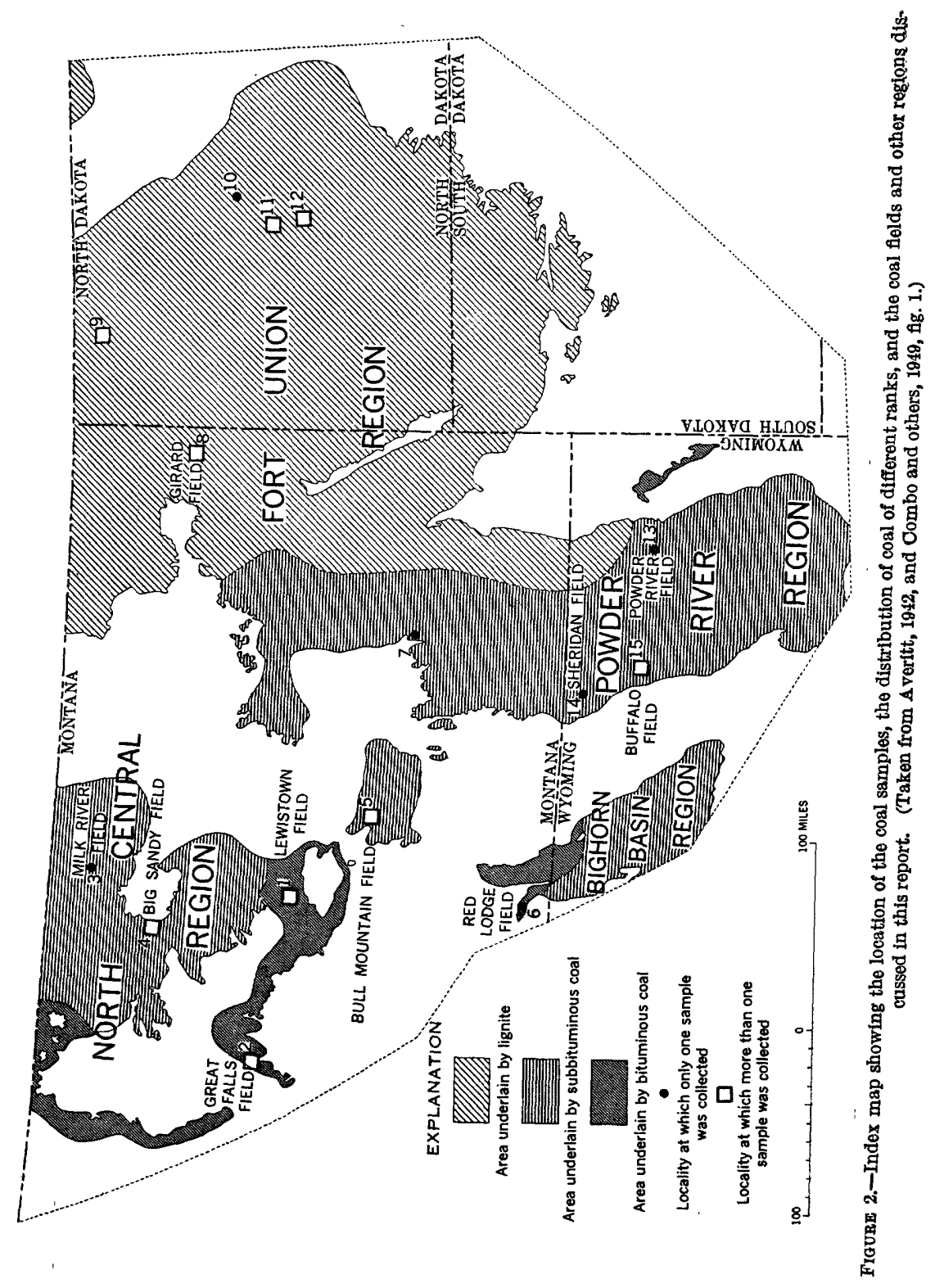




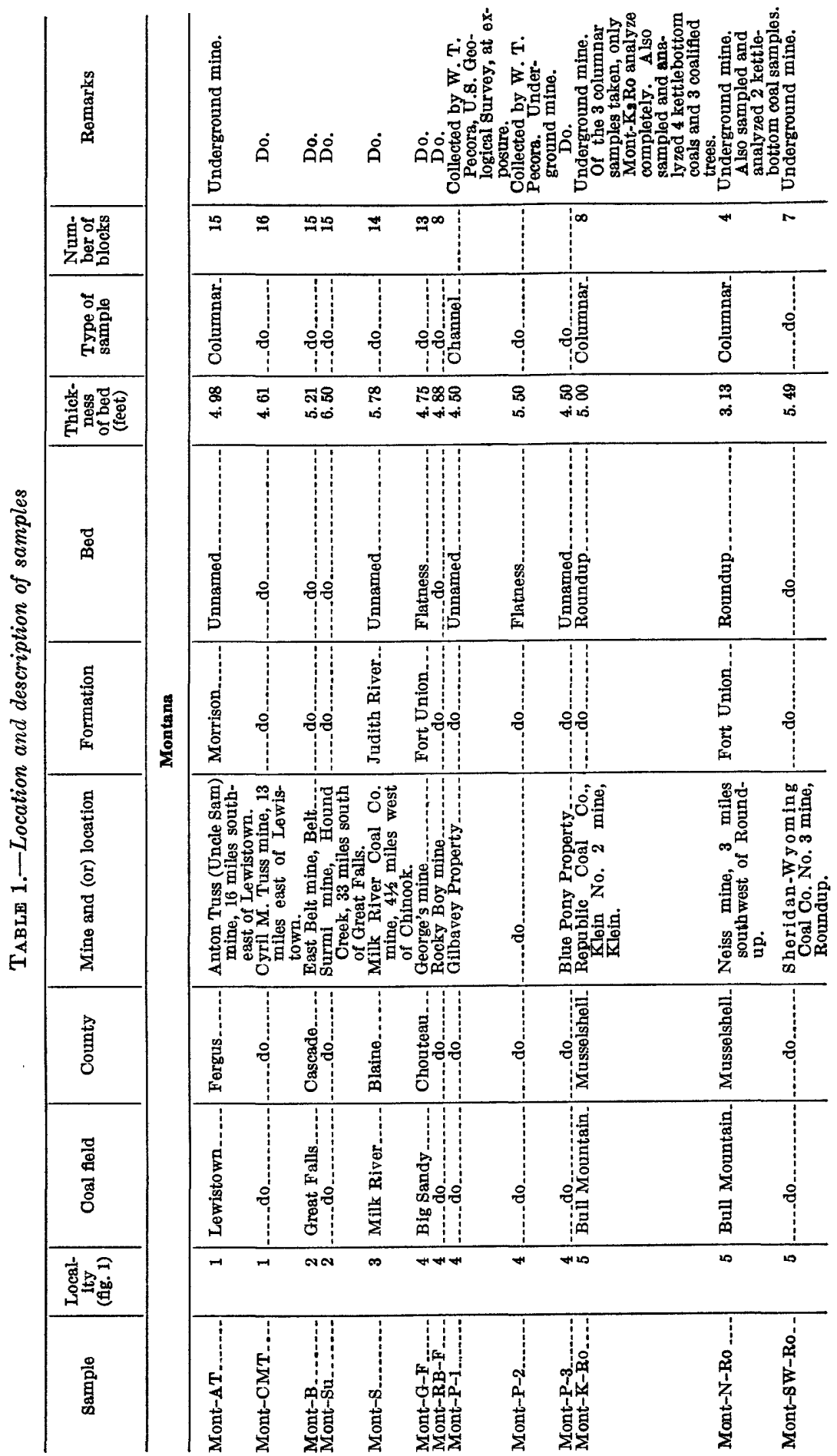


COALS OF NORTHERN GREAT PLAINS COAL PROVINCE A-9

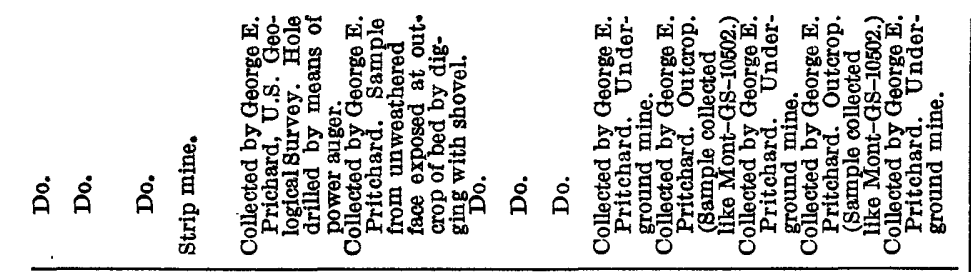

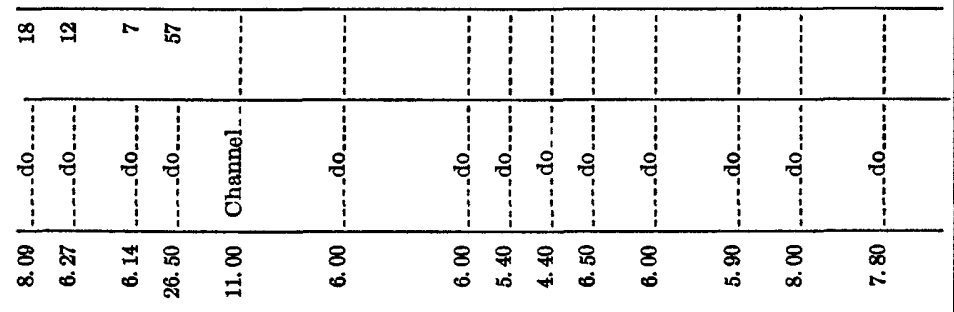

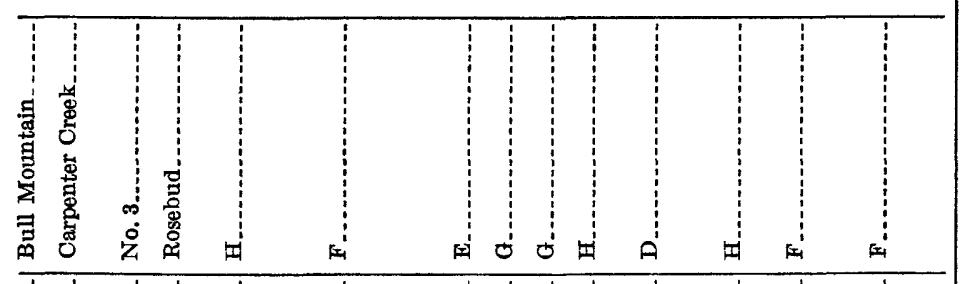

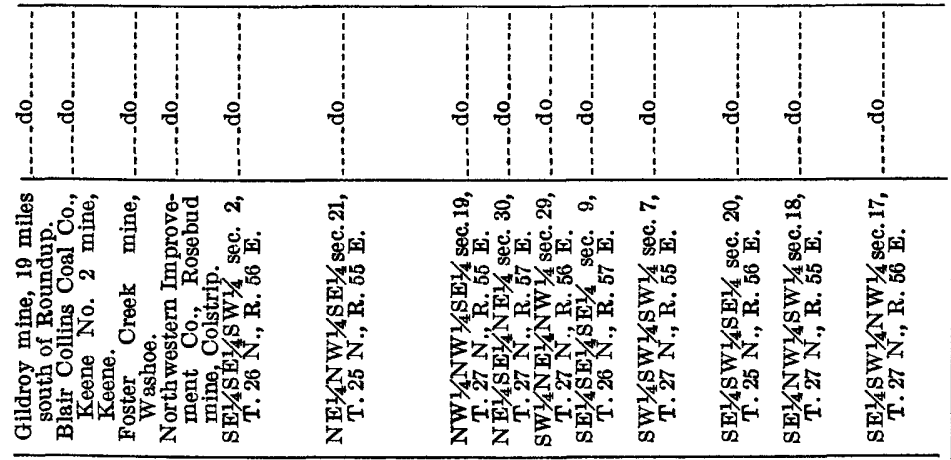

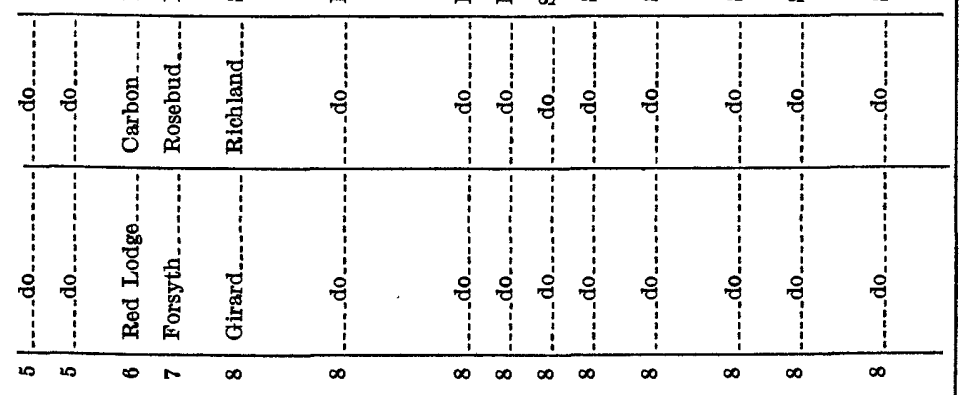

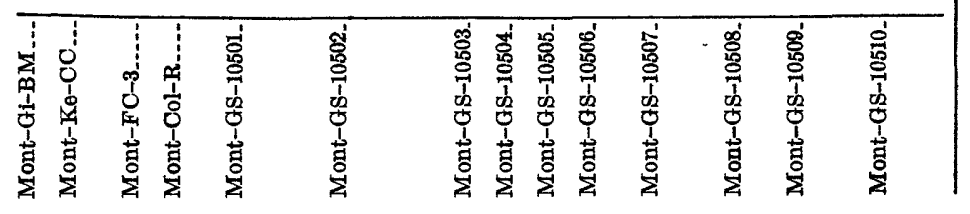




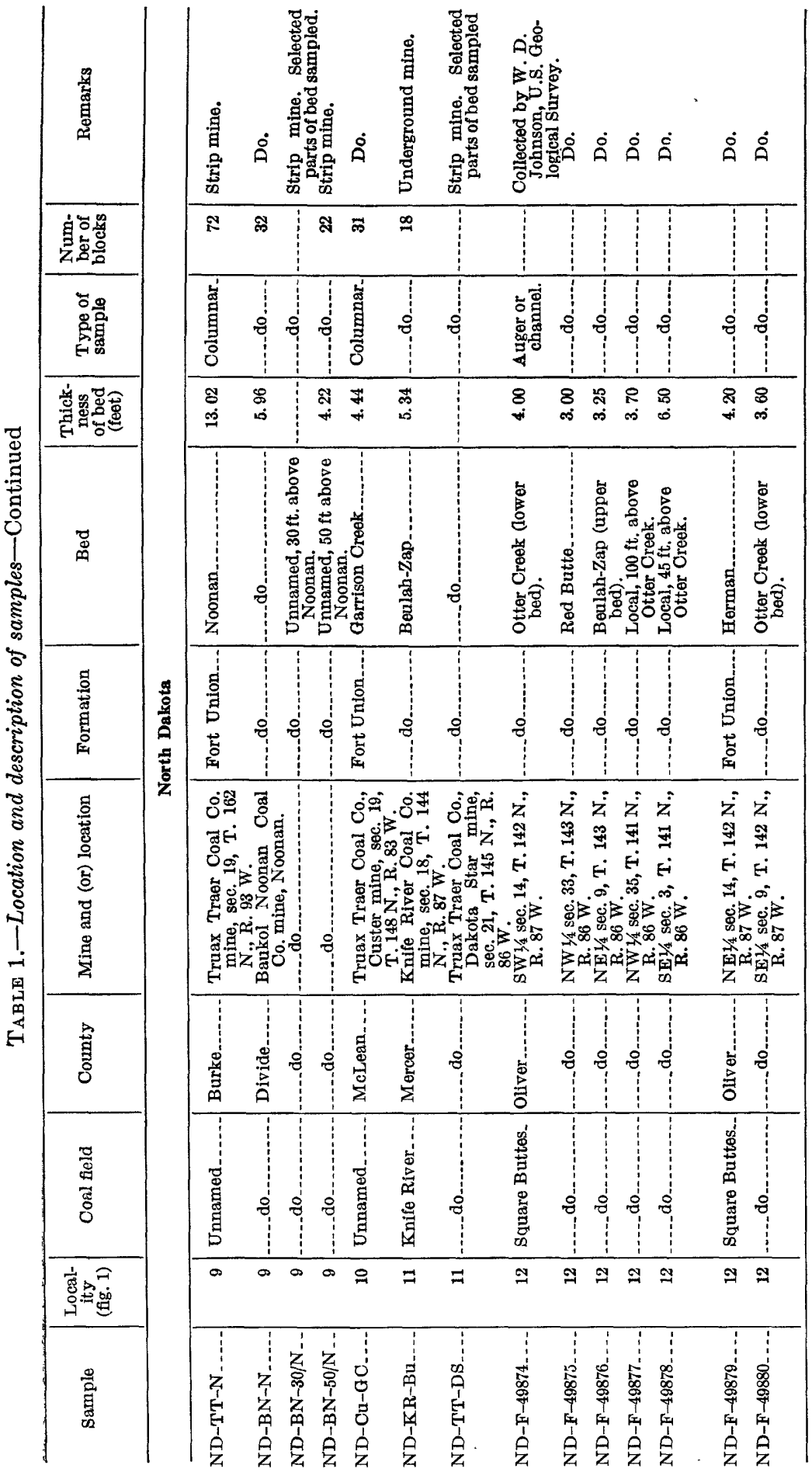


COALS OF NORTHERN GREAT PLAINS COAL PROVINCE A-11

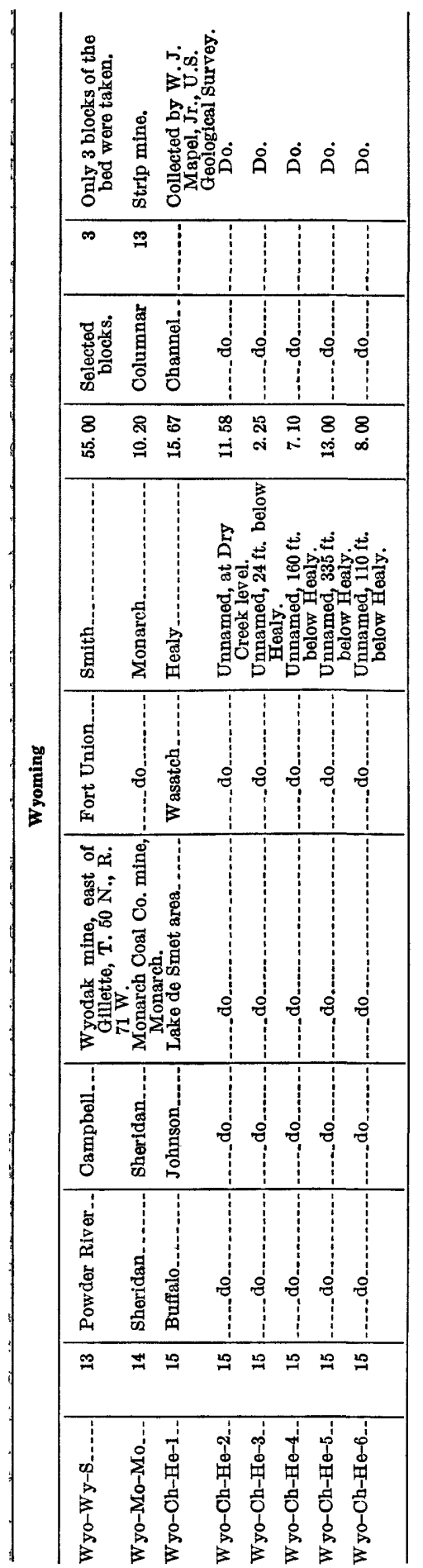


Many beds may be in the coal-bearing formations in the areas where fieldwork was done; however, few beds were sampled. Thus in the Bull Mountain field where 26 beds have been mapped, only 3 were sampled. In the Girard field, of 7 principal and several local beds known, 5 were sampled. In North Dakota only 1 bed was sampled in each of four counties, Burke, Divide, McLean, and Mercer, although there are 5 to 8 beds. In the same State, 6 samples were collected in Oliver County although there are 10 persistent and several local beds. Sampling was similarly limited elsewhere in the province.

In general the coal-bearing formations gradually dip eastward and northeastward away from the Rocky Mountain front toward the Williston basin; to the east and south of the basin the dip is also toward the center of the basin. Many deviations that reverse the dip on a small order do not seriously affect the general picture, but several large structures, such as the Black Hills, the Bearpaw Mountains, and the intrusive masses of central Montana, disrupt it considerably. Near these uplifts the formations of Tertiary age have been eroded and older rocks are exposed.

In the Fort Union region of Montana and North Dakota, although there are local reversals of dip the general dip of the beds is perhaps 10 to 20 feet per mile toward the Williston basin. Two major tectonic complications in this structural picture of the area are the Cedar Creek anticline, which lies across the Montana-North Dakota boundary, and the Black Hills uplift, where the dips are much steeper.

The Black Hills uplift also is a factor in determining the structure of the Powder River Basin. Located between the Black Hills and the Bighorn Mountains, this basin is a long and broad feature with gentle dips in the center and gradually steepening dips along the edges of the basin because of the uplift of the two mountain areas. The basin trends north-northwestward, and in the northern part it joins the Fort Union region without any distinct structural boundary.

In the north-central region of the province the structure is complicated by the Bearpaw Mountains. The formations dip gradually eastward from the Sweetgrass arch to the vicinity of the Bearpaw Mountains; in the latter area the dip is usually plainsward from the slopes of the uplift. There are several anomalies in the immediate vicinity of the igneous masses and at some places dips as high as $20^{\circ}$ toward the mountains are recorded. Many faults are also present, and in the Big Sandy coal field a section of the Fort Union formation is preserved in a down-faulted block. Several coal beds occur in this formation, whereas in all the surrounding area the surface rocks are of Cretaceous age unless overlain by Pleistocene gravel and alluvium.

In the Great Falls and Lewistown coal fields the structure is affected by the uplifted Little Belt and Big Snowy Mountains to the south. 
The beds all dip northward away from the uplifts. Near the mountains the dips are as steep as $10^{\circ}$ to $15^{\circ}$, whereas a short distance away the angle of the dips recedes to about $3^{\circ}$ to $5^{\circ}$. In the eastern part of the Lewistown coal field the structure is complicated by intrusive rocks of the Moccasin and Judith Mountains.

The Bull Mountain coal field is a shallow syncline in which the beds of the Fort Union have been preserved. The syncline trends northwestward and the dip of the beds ranges from $1^{\circ}$ to $5^{\circ}$ toward its center; to the northwest the beds steepen as much as $30^{\circ}$. To the southwest the beds of the Fort Union are continuous with those of the Fort Union region; in all other directions along the edges of the Bull Mountain coal field, the Fort Union has been eroded and Cretaceous beds are exposed.

Although the Red Lodge coal field of the Bighorn Basin is considered a part of the Rocky Mountain coal province, it is included in this report because geologically it is a part of the sequence of deposition of the Northern Great Plains coal province. The Red Lodge coal field lies at the foot of the Beartooth Mountains and the beds dip southwest toward them. Near Red Lodge, dips of $18^{\circ}$ have been noted and southward and eastward the angle of dip decreases. To the southeast the section gradually rises and Cretaceous rocks are exposed on the eastern flank of the Bighorn Basin.

\section{COLLECTION AND PREPARATION OF SAMPLES}

\section{SAMPIING OF COAL}

The sampling by the authors was done on fresh exposures of coal either at strip mines or in underground mines. This, of course, limited the number of samples that could be collected to those from the accessible mines in operation at the times of the fieldwork. Many small mines that operate only during the winter were not sampled.

Because the concentration of some minor elements varies considerably from the top to the bottom of a bed, samples were collected in a vertical sequence of blocks through the thickness of a bed. Natural changes in the lithology of the coal usually determined the thickness of the block, but where coal was fairly uniform blocks were chosen in sizes easy to handle and pack. In all sampling by the authors, the primary consideration was the preservation of variations in the sedimentary sequence of a bed.

Usually a columnar sample of coal was taken from a working face or at a pillar. Channels were cut on each side of the selected area and the blocks were broken away and laid on the ground in sequential order, and numbered to preserve the sequence from the top of the bed to the bottom. Sometimes the roof and floor of the mine also were sampled. When the cutting was completed each block was measured 
and recorded; the width and length generally ranging from 4 by 4 to 6 by 6 inches. The appropriate descriptive label was taped to the top of each block, which was then wrapped in newspaper and aluminum foil. A second label placed on the outside wrapping identified the block by code and number.

Channel or auger samples were usually from areas where no sampling was done by the authors. While the variation of the minorelement content within a bed cannot be determined from such samples, the samples are valuable in determining the areal distribution of the minor-element content of coal beds.

\section{LABORATORY PREPARATION}

In the laboratory, the samples were opened and examined. Part of a block was split or sawed off and was ground to pass through an 8-mesh sieve. A fraction of these samples was then ground to pass through a 100-mesh sieve. The remainder of the coarse sample was stored for use in further studies. The fine powder was the working fraction.

A 10.gram sample of the finely ground coal was weighed and placed in a uniform layer in an aluminum tray, $1 / 2$ inch deep, $3 \frac{14}{4}$ inches wide, and 4 inches long. Trays were placed in a muffle furnace and the door of the muffle was lowered so that there was about a $1 / 2$-inch opening at the bottom to allow air to enter and expedite oxidation of the coal.

The furnaces have automatic control units to regulate the temperature. Initially, the temperature control was set at $200^{\circ} \mathrm{C}$ and kept there for several hours. The temperature was then increased in steps of $75^{\circ}$ to $100^{\circ} \mathrm{C}$ every hour or two, until $450^{\circ} \mathrm{C}$ was reached, and this temperature was maintained until all organic matter in the coal samples was oxidized. To insure uniform ashing, the trays were periodically removed from the furnace, shaken, and rotated in position on replacement in the furnace. Finally, the ash was weighed and placed in properly labeled bottles.

The germanium and molybdenum contents of the ashes were determined spectrophotometrically; one-tenth of the ash sample, equal to the ash from one gram of coal, was used for each of the elements. If an analysis showed a high content of either of these elements in a low-ash coal, that is, approximately 5 percent ash or less, the sample was sent to the spectrographic laboratory for determination of the 15 minor elements studied for this report.

\section{FLOTATION OF HIGH-ASH COALS}

If the coal yielded more than about 5 percent ash, a 40-gram sample was divided into approximately equal amounts and placed into four 100-ml centrifuge tubes. A solution of ethyl alcohol and carbon 
tetrachloride of the required specific gravity was added and the sample was centrifuged for 20 minutes at $800 \mathrm{rpm}$. The float cake was loosened with a spatula, and, with the liquid part was decanted into a Büchner funnel. The sink fraction at the bottom of the tube was allowed to dry sufficiently to be scraped out of the tube into evaporating dishes. Both fractions were dried in an oven at $60^{\circ}$ to $70^{\circ} \mathrm{C}$.

The specific gravity of the liquid that was used varied with the ash content and structure of the coal sample. It was desired to obtain a float, or "pure", coal, fraction that was representative of the coal sample. At least 50 percent of the organic matter should be floated; this however was not always possible. Specific gravities of 1.30 and 1.32 were used for ash contents of 5 to 10 percent. Above this, 1.34 was used for ash contents of about 15 percent, and 1.36 for ash contents of about 20 percent or more. For coals with a very high ash content, 30 to 50 pereent, specific gravities of 1.40 to 1.60 were used. The structure of the coal influenced the yield; if the coal had large vitrain bands, the float fraction yield at any given specific gravity was higher than that from a microbanded coal. Table 2 lists the samples collected in the province and shows those which were composited and floated, as well as the flotation data.

It was recognized early in this work that analyses of coal samples which were relatively free of extraneous materials were more meaningful than those of samples that were "contaminated" by clastic or secondary ash. Improved laboratory facilities in 1955 permitted us to use flotation procedures on a larger number of samples. Many of the coal samples with a high ash content listed in the tables were analyzed prior to 1955 .

The minor-element content of high-ash coal that has been cleaned by flotation has more significance in geochemical studies than the minor-element content of the raw coal, even though the results on the raw coal are recalculated to an ash-free coal basis. In our opinion, the recalculation method introduces errors that the analyses of the ash from a coal cleaned by flotation would not have. In the first place, the concentration of minor elements in the coal can be more quantitatively determined when extraneous materials in the ash are removed, thus the concentration of elements that could not be detected in the ash of the raw coal can be evaluated in the ash of the cleaned coal. Second, the unknown factor of the amount of minor elements in the clastic material is removed to a large extent and the analytical results obtained are more closely related to the minorelement content of the coal substance. On the other hand, in recalculating the minor-element concentration to an ash-free basis all the minor elements are assumed to be in the coal substance, an assumption that may be erroneous; this is particularly true for zinc, which 
TABLE 2.-Data on the compositing and flotation of samples

\begin{tabular}{|c|c|c|c|c|c|}
\hline Block Nos. & $\begin{array}{c}\text { Percent } \\
\text { ash of } \\
\text { whole coal }\end{array}$ & $\begin{array}{l}\text { Speciffo } \\
\text { gravity }\end{array}$ & $\begin{array}{l}\text { Percent of } \\
\text { float } \\
\text { fraction }\end{array}$ & $\begin{array}{l}\text { Percent ash } \\
\text { of float } \\
\text { fraction }\end{array}$ & Remarks \\
\hline \multicolumn{6}{|c|}{ Mont-Su } \\
\hline $\begin{array}{r}4-7 \\
8-11 \\
12-14\end{array}$ & $\begin{array}{l}\text { 15. } 99 \\
31.87 \\
34.14\end{array}$ & $\begin{array}{l}\text { 1. } 32 \\
\text { 1. } 40 \\
\text { 1. } 40\end{array}$ & $\begin{array}{l}27.83 \\
15.51 \\
11.41\end{array}$ & $\begin{array}{l}2.19 \\
7.21 \\
6.28\end{array}$ & $\begin{array}{l}\text { Not including block } 6 \text {. } \\
\text { Not including block } 9 \text {. }\end{array}$ \\
\hline
\end{tabular}

Mont-S

\begin{tabular}{r|r|r|r|r|r}
\hline $2-3$ & 7.15 & 1.32 & 17.66 & 5.38 & \\
$4-7$ & 12.55 & 1.34 & 11.21 & 6.18 & \\
$9-11$ & 10.29 & 1.36 & 70.38 & 5.56 & \\
$12-13$ & 13.41 & 1.34 & 30.65 & 2.09 & \\
\hline
\end{tabular}

Mont-G-F

\begin{tabular}{r|r|r|r|r|r}
\hline $1-3$ & 43.01 & 1.40 & 36.24 & 6.59 & \\
$4-6$ & 16.64 & 1.40 & 34.82 & 7.39 & \\
$7-9$ & 9.87 & 1.32 & 17.43 & 3.99 & \\
$12-13$ & 7.69 & 1.32 & 15.06 & 3.35 & \\
\hline
\end{tabular}

Mont-RB-F

\begin{tabular}{|c|c|c|c|c|c|}
\hline $\begin{array}{l}1-2 \\
3-5 \\
6-8\end{array}$ & $\begin{array}{r}35.78 \\
15.78 \\
9.57\end{array}$ & $\begin{array}{l}1.40 \\
1.34 \\
1.32\end{array}$ & $\begin{array}{l}24.33 \\
32.84 \\
37.44\end{array}$ & $\begin{array}{l}\text { 6. } 34 \\
\text { 3. } 69 \\
\text { 5. } 33\end{array}$ & \\
\hline \multicolumn{6}{|c|}{ Mont-K, $-R_{0}$} \\
\hline 2 & 9.58 & 1. 32 & 27.26 & 6. 73 & \\
\hline \multicolumn{6}{|c|}{ Mont-SW-Ro } \\
\hline $\begin{array}{l}1 \\
2\end{array}$ & $\begin{array}{r}19.52 \\
7.94\end{array}$ & $\begin{array}{l}1.34 \\
1.32\end{array}$ & $\begin{array}{r}7.07 \\
18.60\end{array}$ & 2.63 & $\begin{array}{l}\text { Float fractions of blocks } 1 \text { and } 2 \\
\text { composited and ashed. }\end{array}$ \\
\hline \multicolumn{6}{|c|}{ Mont-Gi-BM } \\
\hline $\begin{array}{r}1-3 \\
4-10 \\
11\end{array}$ & $\begin{array}{r}7.62 \\
5.82 \\
23.60\end{array}$ & $\begin{array}{l}\text { 1. } 32 \\
\text { 1. } 32 \\
\text { 1. } 36\end{array}$ & $\begin{array}{l}49.53 \\
75.45 \\
42.09\end{array}$ & $\begin{array}{r}3.23 \\
3.24 \\
11.86\end{array}$ & \\
\hline \multicolumn{6}{|c|}{ Mont-FC-3 } \\
\hline $\begin{array}{r}T \text { and } 1 \\
2-3 \\
4-6\end{array}$ & $\begin{array}{r}18.88 \\
8.08 \\
9.72\end{array}$ & $\begin{array}{l}\text { 1. } 34 \\
\text { 1. } 32 \\
1.32\end{array}$ & $\begin{array}{l}20.94 \\
23.07 \\
19.90\end{array}$ & $\begin{array}{l}\text { 4. } 83 \\
\text { 4. } 01 \\
4.86\end{array}$ & $\mathbf{T}$ is top block of the column. \\
\hline
\end{tabular}


COALS: OF NORTHERN GREAT PLAINS COAL PROVINCE A-17

TABLE 2-Data on the compositing and flotation of samples-Continued

\begin{tabular}{|c|c|c|c|c|c|}
\hline Bloek Nos. & $\begin{array}{c}\text { Percent } \\
\text { ash of } \\
\text { whole coal }\end{array}$ & $\begin{array}{l}\text { Speciffe } \\
\text { gravity }\end{array}$ & $\begin{array}{c}\text { Percent of } \\
\text { float } \\
\text { fraction }\end{array}$ & $\begin{array}{c}\text { Percent ash } \\
\text { of float } \\
\text { fraction }\end{array}$ & Remarks \\
\hline \multicolumn{6}{|c|}{ Mont-Ke-CC } \\
\hline $\begin{array}{r}1-2 \\
9-11\end{array}$ & $\begin{array}{r}14.94 \\
9.66\end{array}$ & $\begin{array}{l}\text { 1. } 36 \\
\text { 1. } 34\end{array}$ & $\begin{array}{l}69.35 \\
83.64\end{array}$ & $\begin{array}{r}10.32 \\
4.79\end{array}$ & \\
\hline \multicolumn{6}{|c|}{ ND.TT-N } \\
\hline $\begin{array}{r}1-4 \\
5-17 \\
18-30 \\
31-43 \\
44-56 \\
57-69 \\
70-72\end{array}$ & $\begin{array}{l}\text { 7. } 11 \\
\text { 6. } 60 \\
5.97 \\
\text { 6. } 68 \\
9.71 \\
7.56 \\
6.45\end{array}$ & $\begin{array}{l}\text { 1. } 32 \\
\text { 1. } 3 \hat{2} \\
\text { 1. } 32 \\
\text { 1. } 32 \\
\text { 1. } 34 \\
\text { 1. } 32 \\
\text { 1. } 34\end{array}$ & $\begin{array}{l}22.48 \\
29.43 \\
38.31 \\
36.40 \\
33.93 \\
45.14 \\
48.83\end{array}$ & $\begin{array}{l}7.10 \\
7.24 \\
6.47 \\
6.80 \\
8.07 \\
6.35 \\
8.17\end{array}$ & Not_including block 20. \\
\hline \multicolumn{6}{|c|}{ ND-Cu-GC } \\
\hline $\begin{array}{r}1-3 \\
4-10 \\
12-17 \\
18-25 \\
26-31\end{array}$ & $\begin{array}{r}\text { 6. } 36 \\
6.72 \\
\text { 6. } 51 \\
8.06 \\
\end{array}$ & $\begin{array}{l}\text { 1. } 32 \\
1.32 \\
1.32 \\
1.32 \\
1.32\end{array}$ & $\begin{array}{l}63.93 \\
44.99 \\
40.56 \\
26.45 \\
63.46\end{array}$ & $\begin{array}{l}\text { 4. } 98 \\
\text { 4. } 45 \\
\text { 6. } 12 \\
\text { 6. } 42 \\
\text { 5. } 23\end{array}$ & Not including block_24. \\
\hline \multicolumn{6}{|c|}{ ND-KR-Bu } \\
\hline $\begin{array}{r}1-6 \\
7-13 \\
14-18\end{array}$ & $\begin{array}{l}10.20 \\
18.08\end{array}$ & $\begin{array}{l}\text { 1. } 32 \\
\text { 1. } 32 \\
1.36\end{array}$ & $\begin{array}{l}24.63 \\
23.18 \\
44.12\end{array}$ & $\begin{array}{r}5.65 \\
6.62 \\
15.39\end{array}$ & Not including block_2. \\
\hline
\end{tabular}

has been shown to concentrate in the sink fractions of some samples. In this case a recalculation to an ash-free coal basis has no meaning, as little or none of the zinc is in the coal substance.

As the present report is limited to the geochemistry of the minor elements of the coal substance the use of the ash-float fraction for the analyses of minor-element content is valid. After sink and float fractions have been analyzed, there is normally a uniformly low amount of minor elements in the ash of the sink fraction and a concentration in the ash of float fractions. As most major coal mining companies clean their coal by flotation, our flotation samples should be more like the coal they sell than the raw coal samples.

\section{COMPOSITE SAMPLES}

Early in this work it became apparent that it would be impossible to analyze each block of coal that was collected throughout the United States and that some means of selection had to be adopted. A method of screening by using germanium was devised, for if concentration of this element was high in a sample most of the other elements also were relatively high in concentrations. Thus, the 
plan for first determining the germanium content was adopted as a basis of selecting samples for later analysis. Later molybdenum was also used. Coal ash samples with high amounts of germanium and molybdenum were analyzed first

Another method which saved time and effort was the preparation of composites of blocks from the poorer parts of the coal beds without completely obscuring their depositional variations

In order to get bed averages to plot areal distributions, samples from the poorer parts of the beds were combined to form composite samples in proportions equal to the thicknesses of the blocks. The number of blocks combined to form one composite sample was determined by the ash contents of the individual blocks. Sequences of blocks that had a fairly uniform ash content were combined; when the ash content of the blocks changed, another composite sample was made. If a large uniform sequence of blocks was made into several composites either the same number of blocks or those of approximately equal thickness were combined.

Another means of evaluation of the blocks to form a composite was the knowledge of the germanium and molybdenum contents. Blocks adjacent to each other, with approximately the same content of either of these elements, were combined.

The above procedures used in making composites preserved, to some extent, the depositional sedimentary changes that took place in the formation of coal beds as well as their geochemical history.

The composite samples were processed in the same manner as the block samples. If the average ash content of the individual blocks in the composite was high, the coal was cleaned by flotation, then ashed; if the average ash was low, the sample was ashed without cleaning.

\section{METHOD OF SPECTROGRAPHIC ANALYSIS}

\section{EQUIPMENT AND IIMITS OF DETECTION}

The analyses of the ash samples were made by a quantitative spectrographic method. The apparatus and operating conditions for the analyses are as follows:

Spectrograph:

Electrodes:
A grating spectrograph, Wadsworth mounting, with a dispersion of $5 \mathrm{~A}$ per $\mathrm{mm}$ in the first order.

A high purity carbon rod of $6 \mathrm{~mm}$ diameter, having a machined cup at one end, is used as the sample electrode (anode). The cup has a $4 \mathrm{~mm}$ inner diameter with a wall $0.5 \mathrm{~mm}$ thick and a crater $6 \mathrm{~mm}$ deep. The counter electrode (cathode) is a graphite rod $3 \mathrm{~mm}$ in diameter. 
Excitation:

Exposure:

Emulsion:

Wavelength region:

Microphotometer:

Emulsion calibration:
A 250-volt ballasted d-c arc, operated at 16 amperes, the analytical gap being maintained at $3 \mathrm{~mm}$ throughout excitation.

Samples and standards arced to completion.

Eastman III-O, developed in DK-50 at $20^{\circ} \mathrm{C}$ for 5 minutes with continuous agitation.

$2300 \mathrm{~A}-4700 \mathrm{~A}$, recorded on two 10-inch plates simultaneously.

Projection comparator microphotometer, using a scanning slit at the plate.

Method of Dieke and Crosswhite (1943), using a twostep filter at the slit.

Analysis lines with limits of detection are tabulated as follows:

Table of analysis lines and detection limits for minor elements

\begin{tabular}{|c|c|c|c|c|c|}
\hline Element & $\begin{array}{c}\text { Wavelength } \\
\text { (angstrom } \\
\text { units) }\end{array}$ & $\begin{array}{c}\text { Limit of } \\
\text { detection } \\
\text { (weight per- } \\
\text { cent of ash) }\end{array}$ & Element & $\begin{array}{c}\text { Wavelength } \\
\text { (angstrom } \\
\text { units) }\end{array}$ & $\begin{array}{c}\text { Limit of } \\
\text { detection } \\
\text { (weight per- } \\
\text { cent of ash) }\end{array}$ \\
\hline B.... & 2497.733 & 0.001 & La.... & 4333. 734 & 0.003 \\
\hline $\mathrm{Be} \ldots$ & $\begin{array}{l}2348.610 \\
3131.072\end{array}$ & $\begin{array}{l}.0001 \\
.001\end{array}$ & Mo. & $\begin{array}{l}000 \% .400 \\
3170.346\end{array}$ & .0005 \\
\hline Od... & 3261.057 & .005 & Ni... & $\begin{array}{r}3414.765 \\
3050.819\end{array}$ & .0005 \\
\hline Oo... & $\begin{array}{l}3453.505 \\
3449.170 \\
3449.411\end{array}$ & $\begin{array}{l}.0005 \\
.001 \\
.002\end{array}$ & & 3175.019 & .002 \\
\hline Or..... & $\begin{array}{l}4254.346 \\
3021.558 \\
3024.350\end{array}$ & $\begin{array}{l}.0001 \\
.001 \\
.005\end{array}$ & V............. & $\begin{array}{l}3152.251 \\
3185.396\end{array}$ & $\begin{array}{l}.005 \\
.001 \\
.001\end{array}$ \\
\hline Ou............... & $\begin{array}{l}3273.962 \\
2824.369\end{array}$ & .0001 & $\mathbf{Y}$ & $\begin{array}{r}1185.406 \\
4374.935 \\
3327.875\end{array}$ & .001 \\
\hline $\mathrm{Ga}_{-}$ & 2943. 637 & .001 & & & \\
\hline Ge... & $\begin{array}{l}2651.178 \\
3039.064\end{array}$ & $\begin{array}{l}.001 \\
.002\end{array}$ & & & \\
\hline
\end{tabular}

The analytical curves were established from the spectra of a series of synthetic standards, prepared by incorporating known amounts of the oxides of the elements into a base material consisting of 60 parts of quartz, 40 parts of microcline, and 1 part of ferric oxides. A series of concentrations ranging from $1.00,0.464,0.215,0.1$. . 0.001 percent were prepared by successive dilution with the base material. Pure powdered graphite was incorporated into each of the standards in the ratio of 1 part of graphite to 4 parts of standard. Whenever possible, analyzed samples were used to validate the working curves. No internal standard was used.

The ash samples were first ground in an agate mortar to assure homogeneity. The samples were then mixed thoroughly with a half weight of the base material and powdered graphite in the ratio of 1 part of graphite to 4 parts of the diluted sample. Thirty milli- 
grams of this mixture was introduced into electrodes and arced in duplicate.

If the concentration of germanium was 0.02 percent or more in the initial analysis, or if any of the other elements determined were present in concentration above the limits of the analytical curves, the samples were further diluted with the base material. By so doing, the composition of the samples approached that of the standards and a more accurate determination was obtained.

\section{PRECISION AND ACCURACY}

The analytical results are, in general, the average of single determinations made on two separate plates. The overall coefficient of variations for the mean of such duplicates for all the elements is \pm 15 percent with a range of 10 to 20 percent, depending upon the nature of the ash, the element, and the concentration of the element.

A comparison of spectrochemical and chemical determinations is possible for only two elements, molybdenum and germanium; the data are shown below. Assuming that the chemical values are correct, the probable error for the spectrographic determinations of both elements is about \pm 30 percent.

Comparison of spectrographic and chemical determinations of molybdenum and germanium.

[Results expressed as part per million of coal]

\begin{tabular}{|c|c|c|c|c|c|}
\hline \multicolumn{3}{|c|}{ Molybdenum } & \multicolumn{3}{|c|}{ Germanium } \\
\hline Sample & Spectrographic 1 & Chemical 2 & Sample & Spectrographic 1 & Chemical \\
\hline $\begin{array}{r}1 \\
2 \\
3 \\
4 \\
5 \\
6 \\
7 \\
8 \\
9 \\
10 \\
11 \\
12 \\
13 \\
14 \\
15 \\
16\end{array}$ & $\begin{array}{c}1.5 \\
3.0 \\
150 \\
68 \\
36 \\
28 \\
7.4 \\
180 \\
1.2 \\
.9 \\
1.9 \\
.27 \\
.3 \\
2.1 \\
.45 \\
.64\end{array}$ & $\begin{aligned} 2.0 \\
3.2 \\
120 \\
60 \\
40 \\
24 . \\
5.7 \\
220 \\
1.5 \\
.9 \\
1.9 \\
.25 \\
.25 \\
1.1 \\
.4 \\
.50\end{aligned}$ & $\begin{array}{l}17 \\
18 \\
19 \\
20 \\
21 \\
22 \\
23 \\
24 \\
25 \\
26 \\
27 \\
28 \\
29 \\
30 \\
31 \\
32 \\
33 \\
34 \\
35 \\
36\end{array}$ & $\begin{array}{l}23 \\
16 \\
12 \\
47 \\
39 \\
19 \\
12 \\
17 \\
15 \\
11 \\
16 \\
39 \\
17 \\
41 \\
32 \\
28 \\
37 \\
34 \\
17 \\
31\end{array}$ & $\begin{array}{r}20 \\
16 \\
11 \\
50 \\
52 \\
14 \\
6 \\
19 \\
12 \\
18 \\
16 \\
45 \\
15 \\
32 \\
37 \\
34 \\
30 \\
36 \\
28 \\
32\end{array}$ \\
\hline
\end{tabular}

1 Nola B. Sheffey, analyst.

- Peter Zubovic, analyst.

- James H. Townsend and Howard M. Cohen, analysts. 


\section{PRESENTATION OF THE DATA}

The spectrographic data upon which this report is based are presented in table 3. In our earlier analyses boron, titanium, yttrium, lanthanum, and tin were not looked for. Wherever the element was below the sensitivity limit of the method, the element is reported as zero. The sizes of the blocks, where available, are given for columnar samples. The sizes of the samples of vitrain and fusain are not given, but those of vitrain 0,5 to $2 \mathrm{~cm}$ thick, those of fusain are generally less than $1 \mathrm{~cm}$ thick. The coalified trees and kettle-bottom coals have no meaningful dimensions. Channel and auger samples are of whole beds.

Table 4 lists the averages of the minor elements in ash and the average ash of each of the samples of beds. The data for 26 channel and auger samples are also included here because they represent averages of the beds in the sampled areas. The averages for the columnar samples were calculated as follows: whenever block samples representing more than 75 percent of the bed were analyzed, the averages of the ash and the elements in the ash are weighted averages of the contribution each block made to the complete columnar sample. When less than 75 percent of the columnar sample was analyzed, arithmetic averages of the analyzed blocks are reported. For the calculation of province averages for each of the elements only those columnar samples of which 50 percent of more of the bed was analyzed were used. Whenever the element is below the limit of detection it is calculated in the averages as a zero. This has very little effect on 10 of the elements that were detected in about 90 percent or more of the samples. Of the others, germanium, which has the highest sensitivity limit ( 0.001 percent, 10 clarkes), would be the one most seriously affected; however, if a value of one-half the sensitivity limit $(0.0005$ percent) were assigned to all samples below the detection limit, the increase of the value for germanium for the average amount in the province would be less than 20 percent.

Table 5 lists the averages for the bed samples in parts per million in coal. Included in this table are all the fusains, vitrains, and other special types of samples. The calculation of these averages was on the same basis as that used for table 4 .

Table 6 lists the average abundance of the elements in the earth's crust (clarkes of the elements), the detection limit in percent and in clarkes, averages of the amounts of the elements in the ashes for the 45 bed samples in calculating the province averages and the clarkes of these averages. Arithmetic averages of the data from all the analyses and the clarke values of these averages are also computed. The averages of the data on elements in West Virgina coals (Headlee and Hunter, 1955, p. 50) are included in this table for comparison. 


\section{A-22 MINOR ELEMENTS IN AMERICAN COALS}

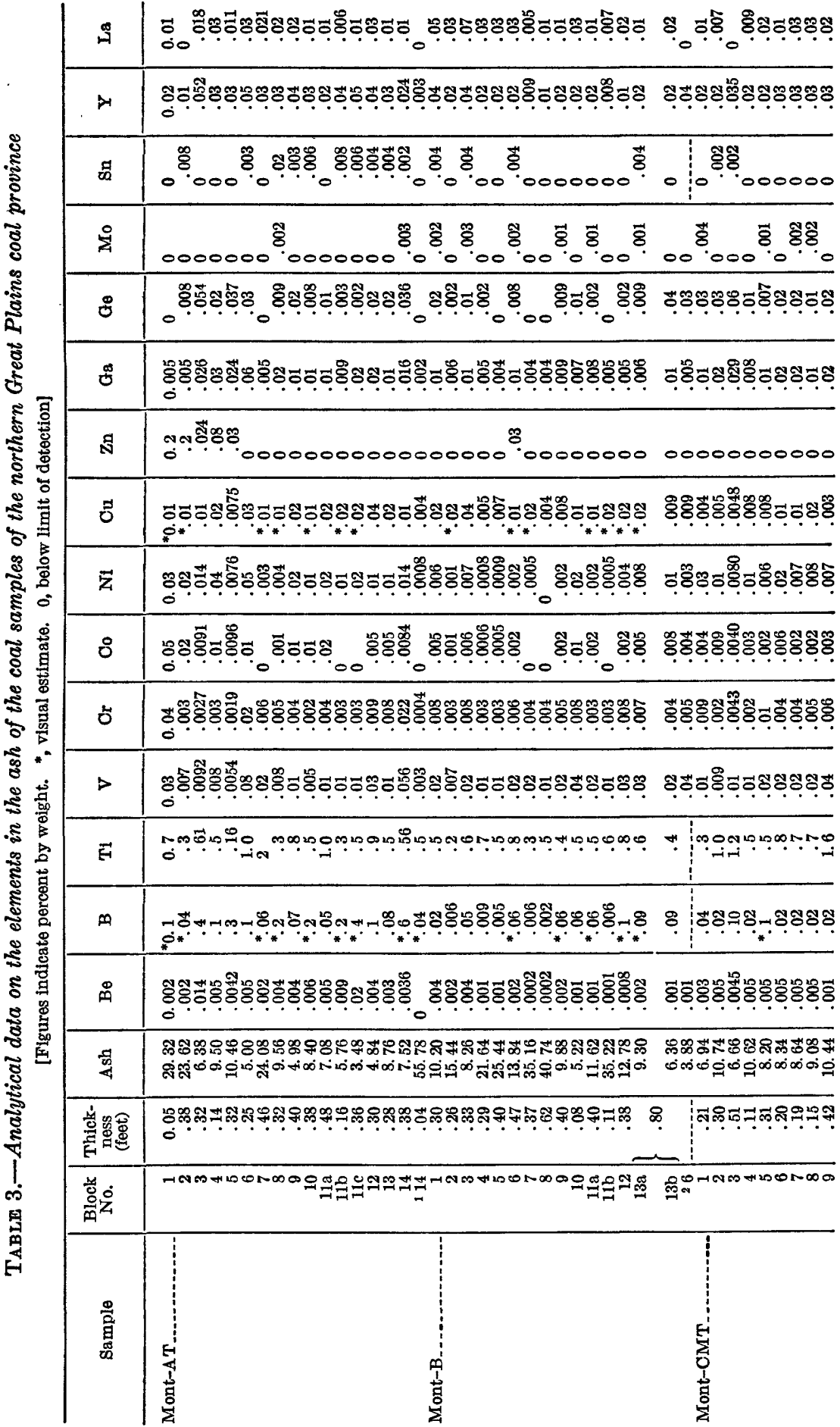


COALS OF NORTHERN GREAT PLAINS COAL PROVINCE A-23.

\begin{tabular}{|c|c|c|c|}
\hline วำำำ & 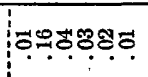 & 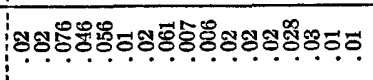 & 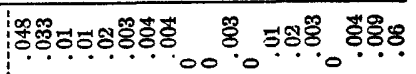 \\
\hline కุำ & \% & క్రిశా. & రి.్రిశ్రి \\
\hline 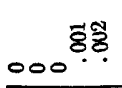 & 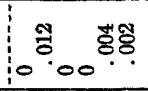 & 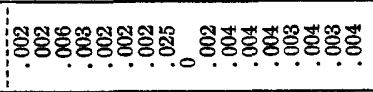 & 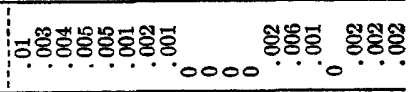 \\
\hline
\end{tabular}

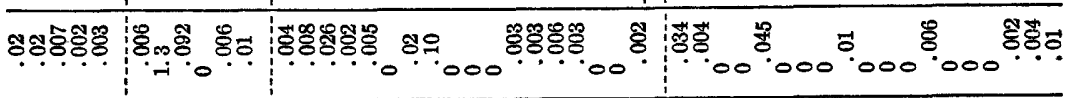

\begin{tabular}{|c|c|c|c|}
\hline 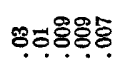 & 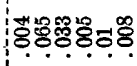 & 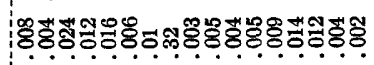 & 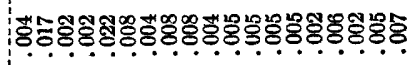 \\
\hline & : & $000000 \div 000000000$ & $000000000000000000^{8}$ \\
\hline
\end{tabular}

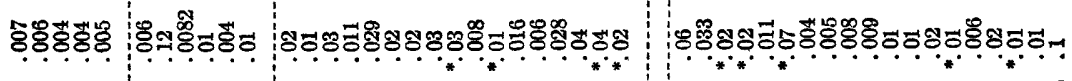

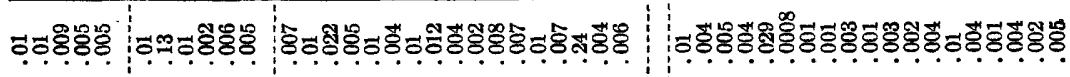

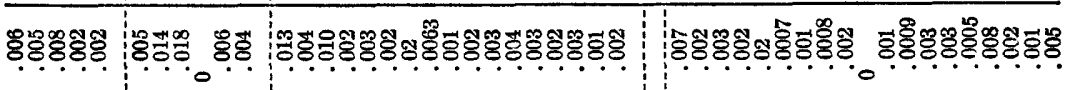

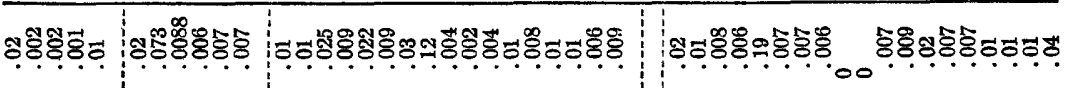

\begin{tabular}{|c|c|c|c|c|c|}
\hline 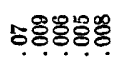 & 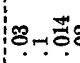 & 5 & 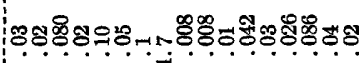 & \multicolumn{2}{|c|}{ 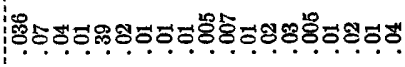 } \\
\hline ஜோ & $\begin{array}{ll}\text { Hin } \\
\pi \text { in }\end{array}$ & m. & m. & $\lim _{-1}^{\infty}$ & \\
\hline 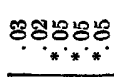 & : & $8 \%$ & $\operatorname{lom}^{0}$ & Anmen & $\underset{\infty}{\infty}$ \\
\hline
\end{tabular}

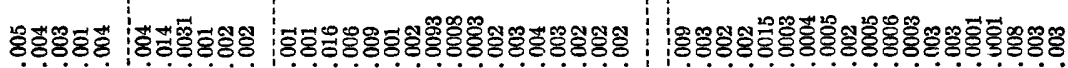

붕요연

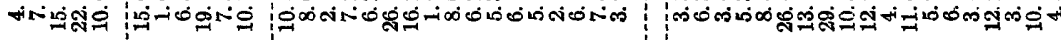

\begin{tabular}{|c|c|c|c|c|}
\hline ํํำสำกำำำ & 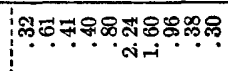 & 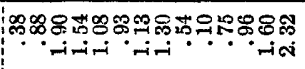 & 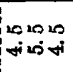 & | \\
\hline
\end{tabular}

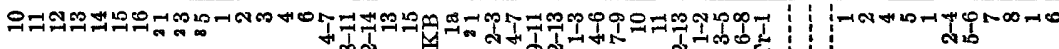

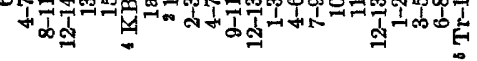

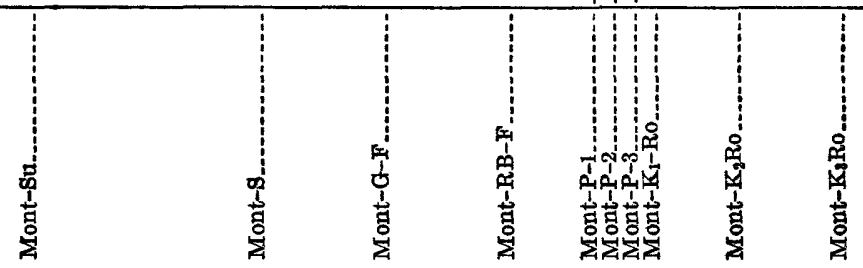




\section{A-24 MmNOR ELEMENTS IN AMERICAN COALS}

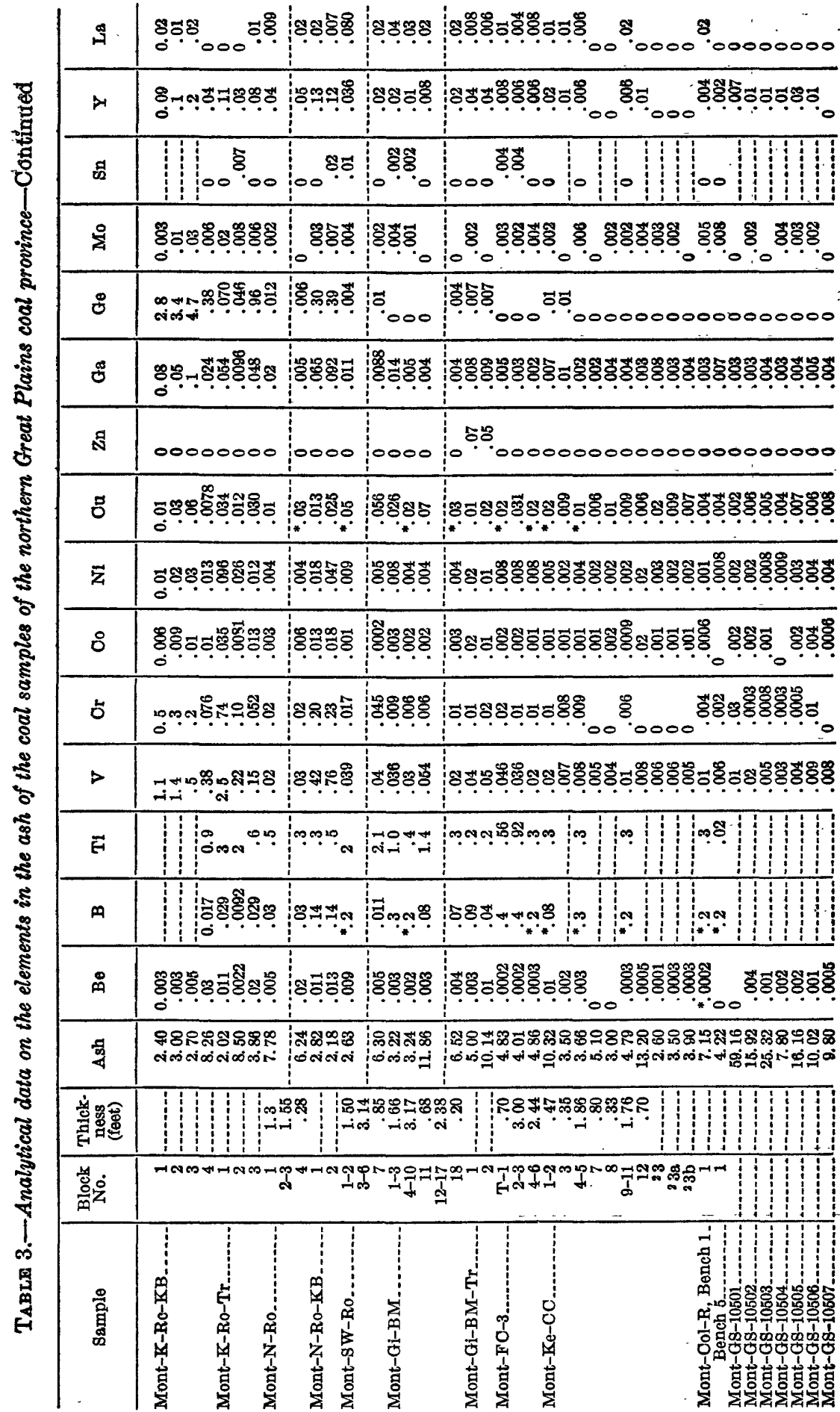


COALS OF NORTHERN GREAT PLAINS COAL PROVINCE A-25

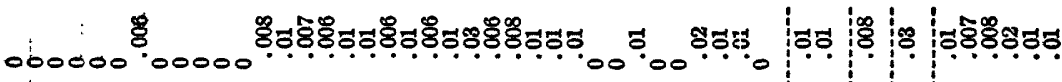

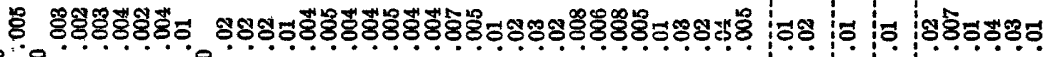

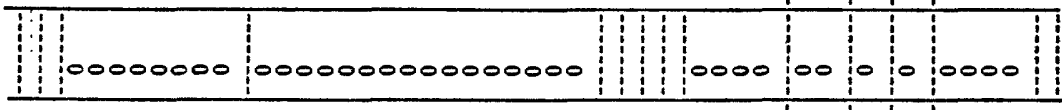

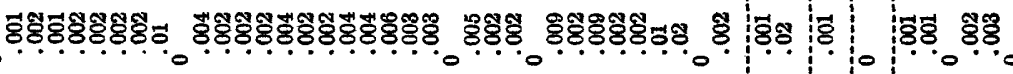

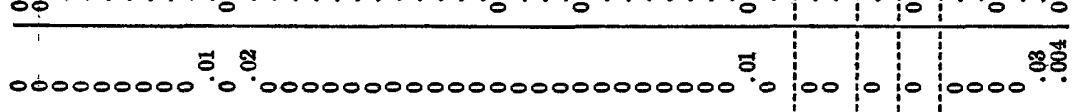

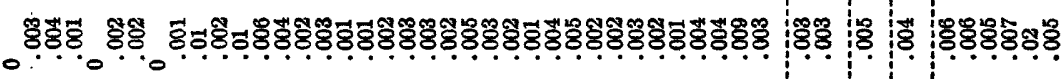

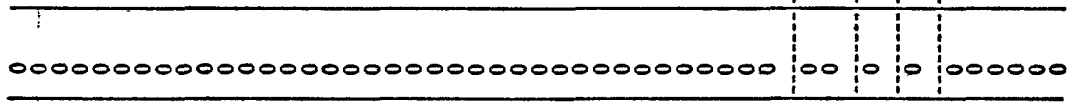

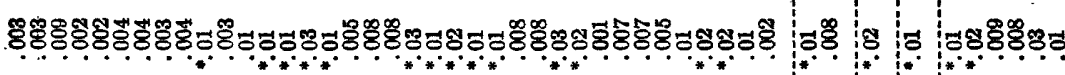

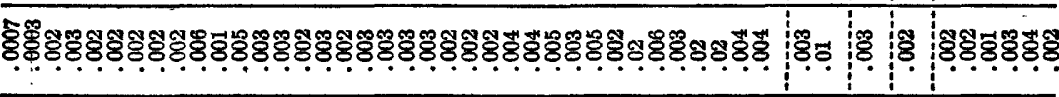

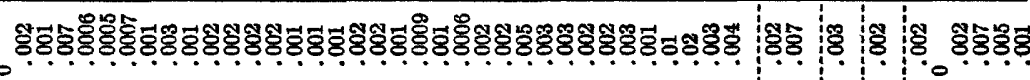

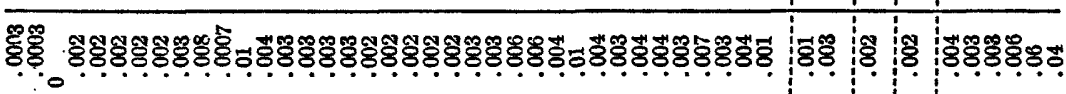

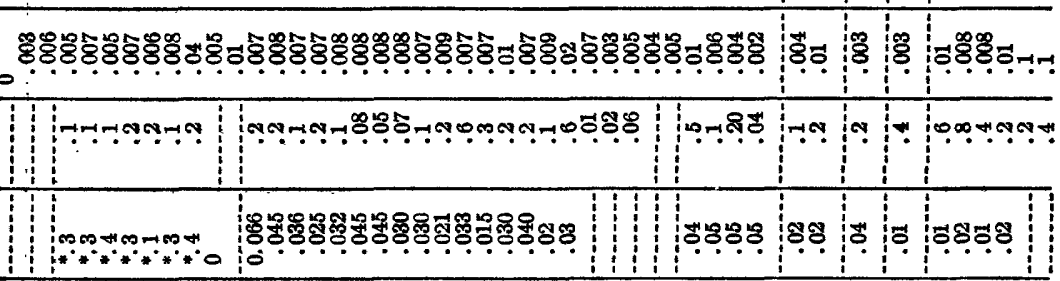

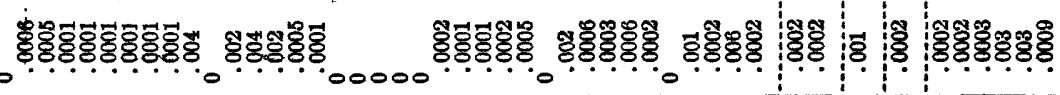

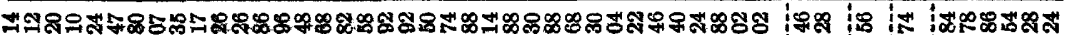

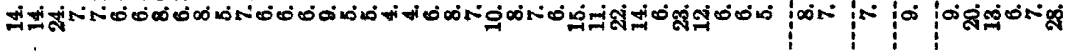

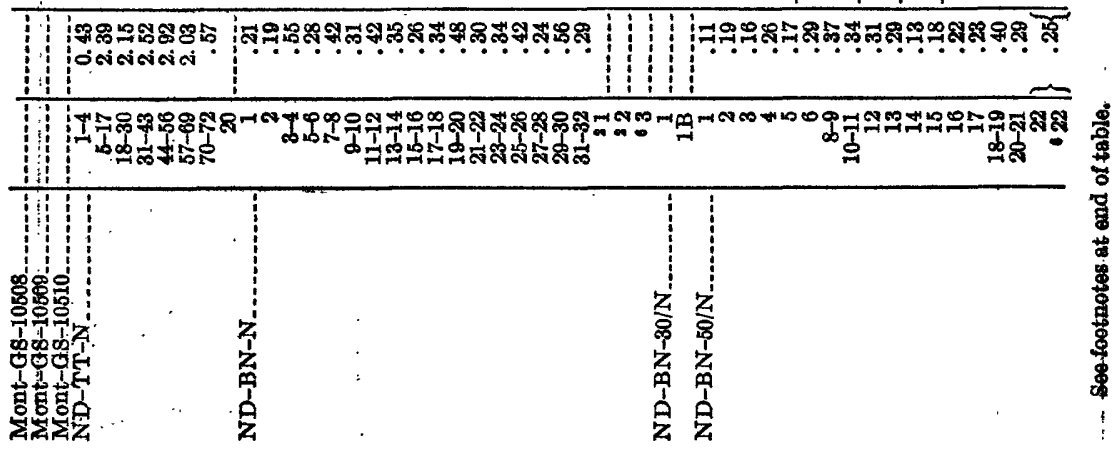




\section{A-26 MTNOR ELEMENTS IN AMERICAN COALS}

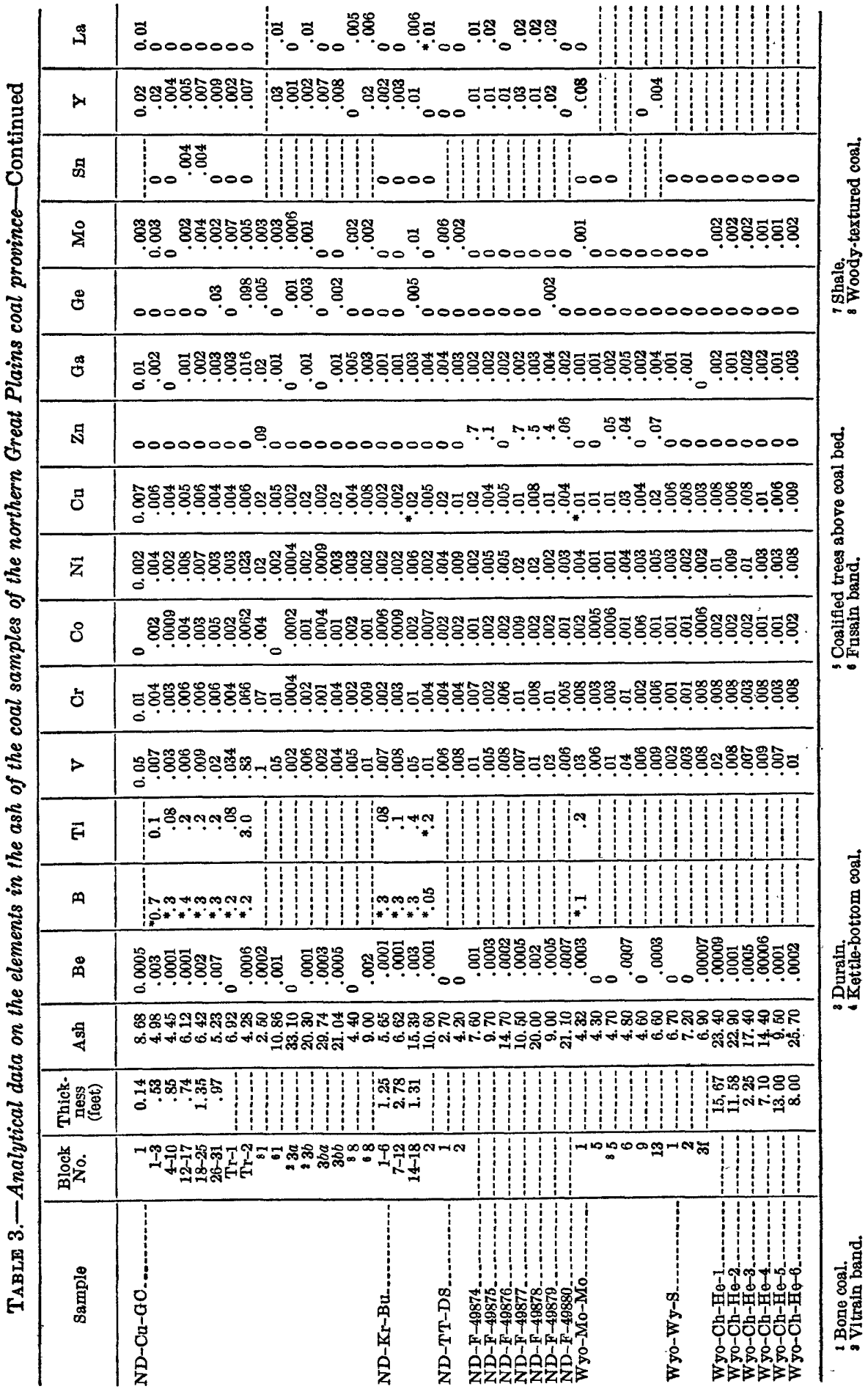


COALS OF NORTHERN GREAT PLAINS COAL PROVINCE A-27

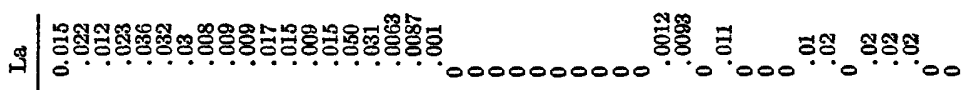

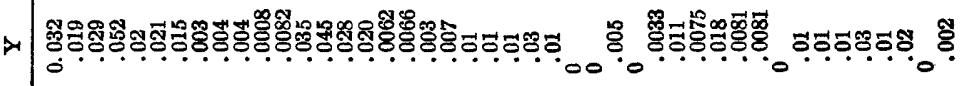

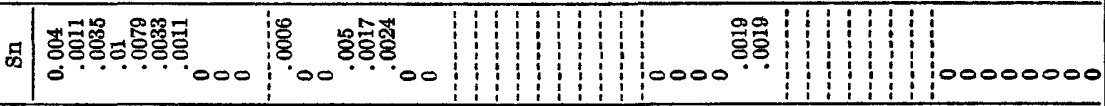

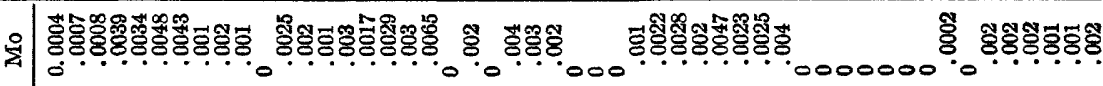

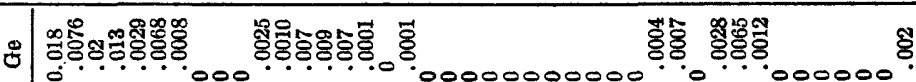

శ్

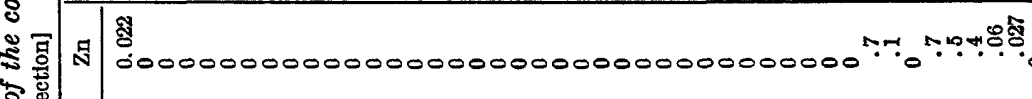

芩

(⿸丆口

亖

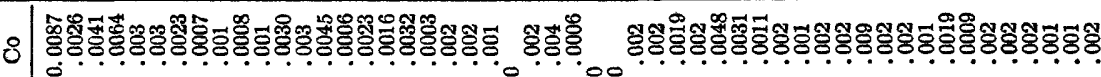

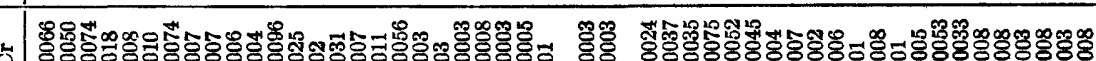

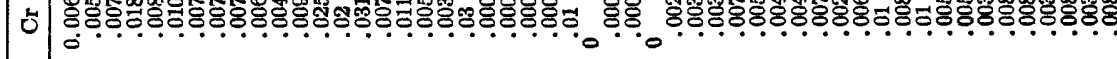

西

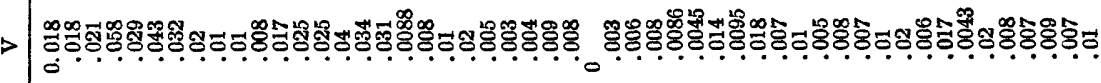

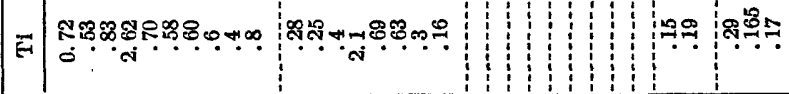

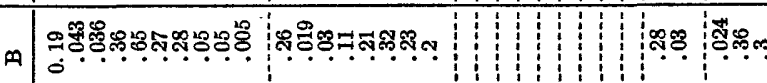

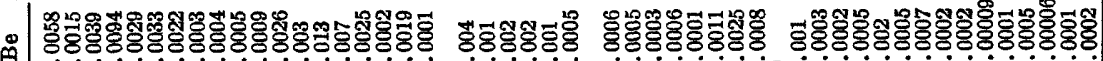

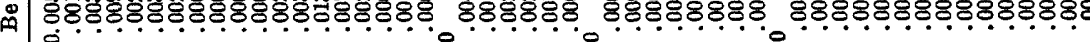

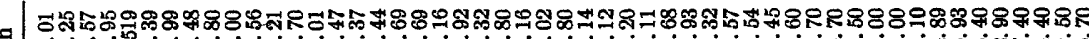

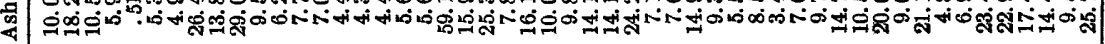

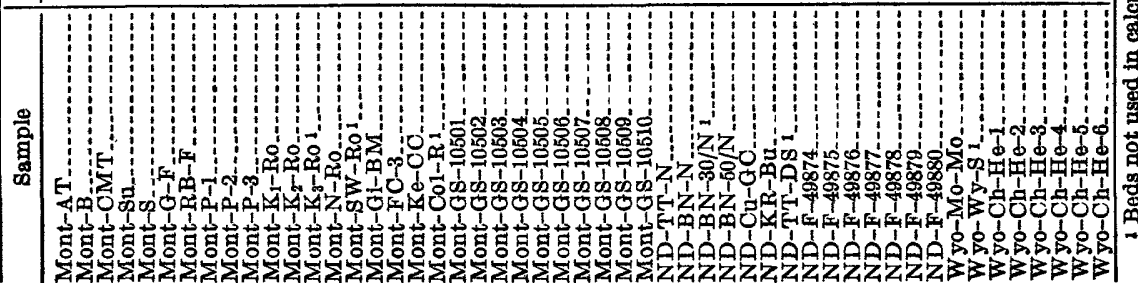




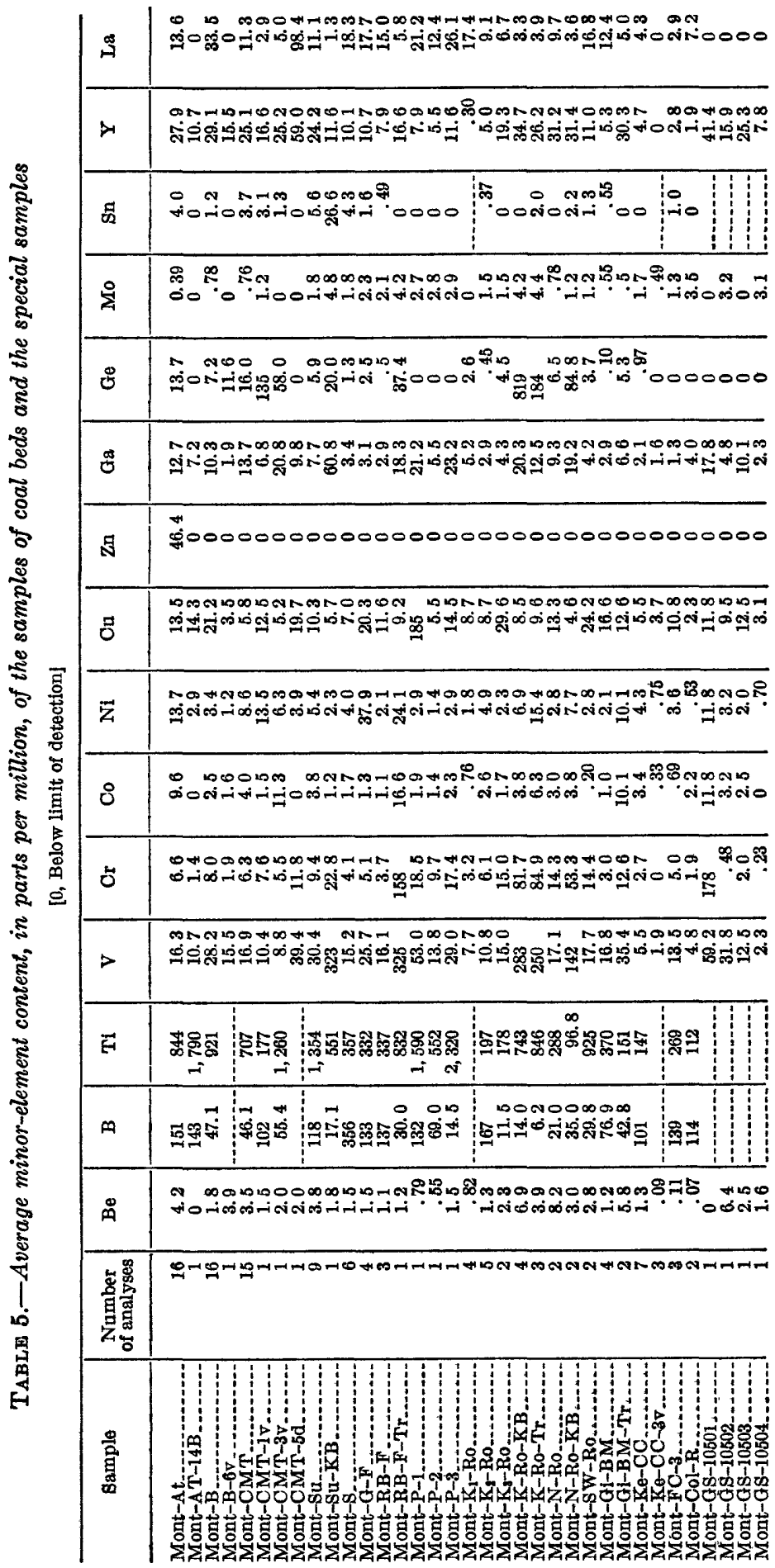




\section{COALS OF NORTHERN GREAT PLAINS COAL PROVINCE A-2\%}

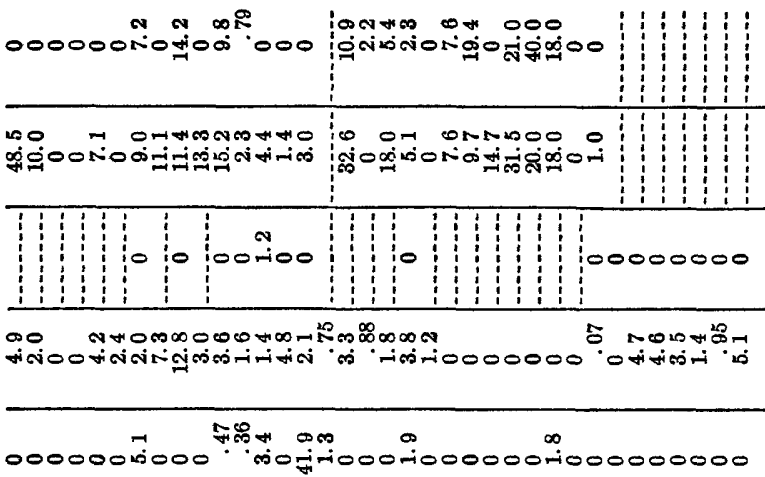

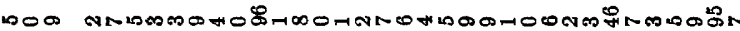

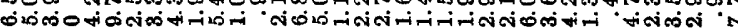

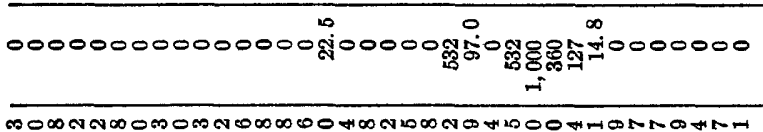

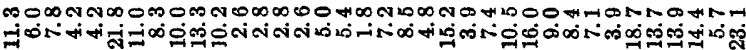

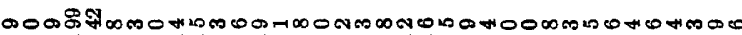

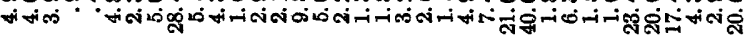

Nol

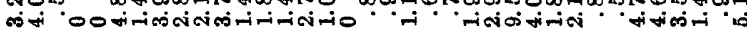

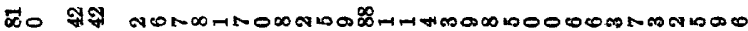
"잉 on on

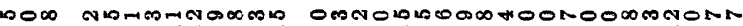
ம0ர்

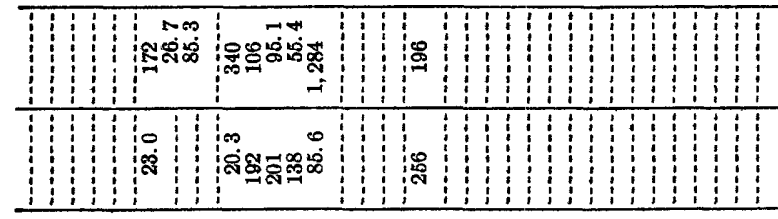

유

ПMमHWW

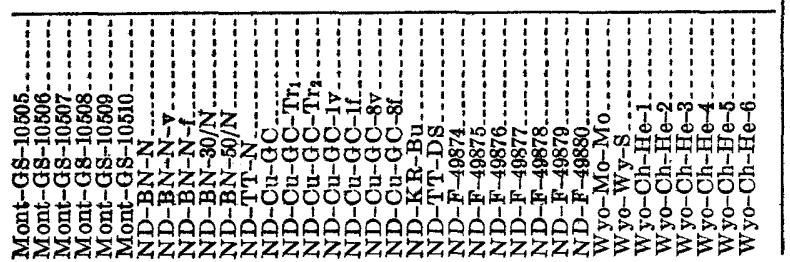


TABLE 6.-Comparison of the minor-element content of ash of coals of this province and of West Virginia and the relation to their clarkes

\begin{tabular}{|c|c|c|c|c|c|c|c|c|c|}
\hline & \multirow{3}{*}{$\begin{array}{c}\text { Clarke } \\
\text { of the } \\
\text { elements } \\
\text { (percent) }\end{array}$} & \multirow{2}{*}{\multicolumn{2}{|c|}{$\begin{array}{l}\text { Spectrographic } \\
\text { sensitivity }\end{array}$}} & \multicolumn{4}{|c|}{$\begin{array}{l}\text { Coal of northern Great Plains coal } \\
\text { province }\end{array}$} & \multirow{2}{*}{\multicolumn{2}{|c|}{$\begin{array}{l}\text { A verage of coal } \\
\text { beds of West } \\
\text { Virginia }\end{array}$}} \\
\hline & & & & \multicolumn{2}{|c|}{$\begin{array}{l}\text { Average of indi- } \\
\text { vidual analyses }\end{array}$} & \multicolumn{2}{|c|}{$\begin{array}{l}\text { A verage of coal } \\
\text { beds }\end{array}$} & & \\
\hline & & Percent & Clarkes & Percent & Clarkes & Percent & Clarkes & Percent $\mathrm{l}$ & Clarkes \\
\hline $\begin{array}{l}\mathrm{B} \\
\mathrm{B} \\
\mathrm{T} 1 \\
\mathrm{~V} \\
\mathrm{Cr} \\
\mathrm{Co} \\
\mathrm{Ni} \\
\mathrm{Cu} \\
\mathrm{Zn} \\
\mathrm{Ga} \\
\mathrm{Ge} \\
\mathrm{Mo} \\
\mathrm{Sn} \\
\mathrm{Y} \\
\mathrm{L} \\
\mathrm{Ash}\end{array}$ & $\begin{array}{l}0.0002 \\
.001 \\
.5 \\
.015 \\
.02 \\
.0023 \\
.008 \\
.007 \\
.01 \\
.0015 \\
.0001 \\
.0001 \\
.004 \\
.002 \\
.004\end{array}$ & $\begin{array}{l}0.0001 \\
.001 \\
.0005 \\
.001 \\
.0001 \\
.0005 \\
.0005 \\
.0001 \\
.02 \\
.001 \\
.001 \\
.0005 \\
.002 \\
.001 \\
.003\end{array}$ & $\begin{array}{l}0.5 \\
1.0 \\
.001 \\
.07 \\
.005 \\
.22 \\
.06 \\
.014 \\
2.0 \\
.67 \\
10.0 \\
5.0 \\
.5 \\
.5 \\
.75 \\
- \\
-\end{array}$ & $\begin{array}{l}0.0025 \\
.15 \\
.59 \\
.065 \\
.02 \\
.004 \\
.0087 \\
.015 \\
.018 \\
.010 \\
.074 \\
.0025 \\
.0027 \\
.021 \\
.012 \\
10.28\end{array}$ & $\begin{array}{c}12.5 \\
150 \\
1.2 \\
4.3 \\
1.0 \\
1.8 \\
1.1 \\
2.1 \\
1.8 \\
6.7 \\
740 \\
25.0 \\
.68 \\
10.5 \\
2.9\end{array}$ & $\begin{array}{c}0.0018 \\
.19 \\
.65 \\
.015 \\
.007 \\
.0021 \\
.0064 \\
.013 \\
.056 \\
.0047 \\
.0022 \\
.0016 \\
.0016 \\
.013 \\
.011 \\
13.42\end{array}$ & $\begin{array}{r}9.0 \\
190 \\
1.3 \\
1.0 \\
.35 \\
.9 \\
.8 \\
1.9 \\
5.6 \\
3.1 \\
22.0 \\
16.0 \\
.4 \\
6.5 \\
2.8 \\
\end{array}$ & \begin{tabular}{|l|}
0.0029 \\
.037 \\
.91 \\
.028 \\
.016 \\
.0079 \\
.037 \\
.049 \\
.043 \\
.018 \\
.0076 \\
.011 \\
.016 \\
\hdashline .026 \\
10.2
\end{tabular} & $\begin{array}{r}14.5 \\
37.0 \\
1.8 \\
1.9 \\
.8 \\
3.4 \\
4.6 \\
7.0 \\
4.3 \\
12.0 \\
76.0 \\
110 \\
4.0 \\
6.5 \\
.-\end{array}$ \\
\hline
\end{tabular}

1 Headlee and Hunter, 1955.

2 Arithmetio averages of beds.

\section{SUMMARY OF THE DATA}

Table 7 summarizes the data in tables 3 to 6 . The maximum and minimum content of each of the elements in the ash of individual samples of coal (table 3), in the coal beds as percent in the ash (table 4), and in the coal beds as parts per million in the coal (table 5), and the averages of the values (table 6) of the preceding three tables make up the data.

The differences between the maximum and minimum value for the amount each of the elements in the three presentations are reasonably reliable for boron, titanium, copper, and perhaps vanadium and nickel. However, the actual differences between the maximum and minimum for the other elements must be considerably greater as the values are below their limits of spectrographic detection in a number of samples, and the minimum values used were these detection limits.

The very large differences between the maximum and minimum amounts of some of the elements as found in the individual samples are noticeable. These differences, especially for vanadium, chromium, and germanium, are primarily the result of the inclusion of the samples of kettle bottom coal and coalified trees. The disparity between the maximum and minimum contents in the beds is much smaller than the disparity between contents in the individual samples in most cases. For zinc, yttrium, and lanthanum, the apparent disparity between contents in beds is higher when contents are expressed in parts per million in coal than it is if expressed in either of the other ways. This is due to the varying amounts of ash in the coal and to 
COALS OF NORTHERN GREAT PLAINS COAL PROVINCE A-31

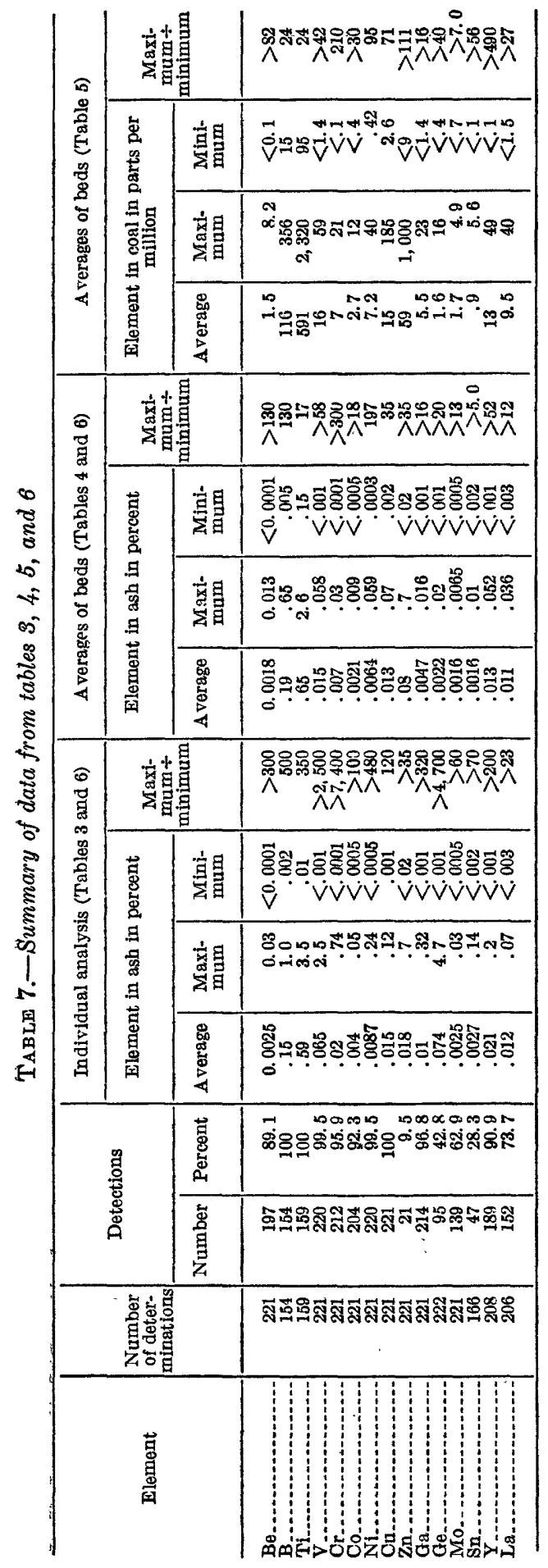


the fact that these elements are not concentrated to any large degree in the special samples from kettle bottom coals and coalified trees. The contribution that the special samples make to the total organic matter in this province is infinitesimally small; if the analytical results were weighted in proportion to the relative amounts of these samples, they would cause only negligible differences from the averages obtained using only samples of bedded coal. As this was not done, the averages of all the individual analyses of the content of the elements in the ashes are much higher than they should be.

The averages calculated from the data on the 45 bed samples, of which more than half of each was analyzed, are the most reliable indicators of the average quantity of the 15 minor elements in coals that have been analyzed in this province. Consequently, the averages of these bed samples are used wherever needed in subsequent discussions.

The clarkes (average abundance in the earth's crust) of the elements in table 6 are derived from four compilations of the abundances of elements in the earth's crust. The values of the clarkes for boron, titanium, vanadium, cobalt, germanium, and tin are taken from some of the figures quoted by Fleischer (1953, p. 4-5). The values of the clarkes for beryllium, chromium, zinc, gallium, and molybdenum are taken from Goldschmidt (1954, p. 213, 545, 260, 320, and 559, respectively). Rankama and Sahama $(1950$, p. 677-685) quote Sandell and Goldich's (1943) figures for nickel and copper in igneous rocks and these values are used in this report. Values of the clarkes for yttrium and lanthanum are taken from Vinogrador (1956, p. 50). Table 6 is a comparison of the contents of these elements in the coal ash from this area and from West Virginia (Headlee and Hunter, 1955, p. 50), with that of their contents in the earth's crust. A comparison of the ash of coals from the northern Great Plains coal province with those from West Virginia coals shows that the latter contains appreciably more cobalt, nickel, copper, gallium, germanium, molybdenum, and tin; the only two elements that are found in larger amounts in the former are boron and zinc. These aspects are discussed on page 42.

\section{DISTRIBUTION OF THE : MINOR ELEMENTS}

\section{DISTRIBUTION IN PETROGRAPHIC CONSTITUENTS OF COAL}

The data from the analyses of several blocks of coal and pieces of vitrain, durain, and fusain selected from these blocks are shown in table 8. There seems to be no invariable pattern of enrichment or loss for any of the elements in these samples.

In the Montana samples, the beryllium content is generally low in the vitrain and durain: : In the North Dakota samples, the fusain 
generally contains more beryllium than the vitrain. No conclusions ean be drawn concerning boron and titanium in either of the two combinations that were analyzed. Other investigators have found that vanadium, chromium, and copper contents are generally higher in the vitrain than in the block samples; however, in these samples the fusain seems to have more of these. elements than the vitrain. Nickel and cobalt contents appear to be low in the vitrain and their content in the fusain is indeterminate. Gallium content is higher in some of the vitrain and durain; the data on its content in the fusain are inconclusive. Germanium is the only element that invariably is associated with vitrain, whereas molybdenum is associated least with it. No conclusions can be formed regarding tin. Yttrium and lanthanum show a high degree of affinity for fusain.

The rather heterogeneous distribution of the elements (table 8) is of interest, because studies of other areas show that these elements are generally associated with the vitrain part of each of the block samples.

TABLE 8.-Distribution of the elements, in parts per million, in petrographic constituents of coal

[0-Below limit of detection]

\begin{tabular}{|c|c|c|c|c|c|c|c|c|c|c|c|c|c|}
\hline \multirow{2}{*}{ Element } & \multicolumn{2}{|c|}{ Mont-B-6 } & \multicolumn{2}{|c|}{$\underset{\text { CMT-1 }}{\text { Mont- }}$} & \multicolumn{2}{|c|}{$\begin{array}{l}\text { Mont- } \\
\text { CMT-3 }\end{array}$} & \multicolumn{2}{|c|}{$\begin{array}{l}\text { Mont- } \\
\text { CMT-5 }\end{array}$} & \multicolumn{3}{|c|}{$\mathrm{ND}-\mathrm{Cu}-\mathrm{GC}-1$} & \multicolumn{2}{|c|}{$\underset{\text { GC-8 }}{\mathrm{ND}-\mathrm{Cu}-}$} \\
\hline & Block & $\begin{array}{l}\text { Vit- } \\
\text { rain }\end{array}$ & Block & $\begin{array}{l}\text { Vit- } \\
\text { rain }\end{array}$ & Block & $\begin{array}{l}\text { Vit- } \\
\text { rain }\end{array}$ & Block & $\begin{array}{l}\text { Du- } \\
\text { rain }\end{array}$ & Block & $\begin{array}{l}\text { Vit- } \\
\text { rain }\end{array}$ & $\begin{array}{l}\text { Fu- } \\
\text { sain }\end{array}$ & $\begin{array}{l}\text { Vit- } \\
\text { rain }\end{array}$ & $\begin{array}{l}\text { Fu- } \\
\text { sain }\end{array}$ \\
\hline Be & $\begin{array}{c}2.8 \\
82\end{array}$ & & 28.1 & 102 & $\begin{array}{r}3.0 \\
67\end{array}$ & & $\begin{array}{c}4.1 \\
82\end{array}$ & 2.0 & 0.4 & 0.05 & 1.1 & 0 & 1.8 \\
\hline 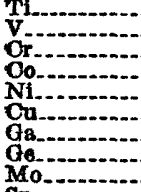 & $\begin{array}{c}1,100 \\
28 \\
8.2 \\
2.8 \\
2.8 \\
14 \\
14 \\
11 \\
2.8\end{array}$ & \begin{tabular}{r|}
16 \\
1.9 \\
1.6 \\
1.2 \\
3.5 \\
1.9 \\
12 \\
0
\end{tabular} & $\begin{array}{r}210 \\
6.9 \\
6.3 \\
2.8 \\
21 \\
2.8 \\
6.8 \\
21 \\
2.8\end{array}$ & $\begin{array}{c}180 \\
10 \\
7.6 \\
1.5 \\
14 \\
13 \\
6.8 \\
135 \\
1.2\end{array}$ & $\begin{array}{c}800 \\
6.7 \\
2.8 \\
2.7 \\
5.3 \\
3.1 \\
18 \\
40 \\
0\end{array}$ & $\mid \begin{array}{c}1,260 \\
8.8 \\
5.5 \\
11 \\
6.3 \\
5.2 \\
21 \\
58 \\
0\end{array}$ & $\begin{array}{c}400 \\
16 \\
8.2 \\
1.6 \\
4.9 \\
6.6 \\
8.2 \\
5.7 \\
.8\end{array}$ & $\begin{array}{c}39 \\
12 \\
0 \\
3.9 \\
20 \\
9.8 \\
0 \\
0\end{array}$ & $\begin{array}{l}44 \\
8.7 \\
0 \\
1.7 \\
6.1 \\
8.7 \\
0 \\
2.6\end{array}$ & \begin{tabular}{|c|}
-25 \\
18 \\
1.0 \\
5.0 \\
5.0 \\
5.0 \\
1.3 \\
.8
\end{tabular} & $\begin{array}{l}-54 \\
11 \\
0 \\
2.0 \\
5.4 \\
1.1 \\
0 \\
3.3\end{array}$ & $\begin{array}{r}-2.2 \\
.9 \\
.9 \\
1.3 \\
1.8 \\
2.2 \\
0 \\
.9\end{array}$ & $\begin{array}{l}-9 \\
8 \\
.9 \\
1.8 \\
7.2 \\
2.7 \\
0 \\
1.8\end{array}$ \\
\hline $\mathbf{Y}$ & $\begin{array}{l}5.5 \\
28 \\
41\end{array}$ & \begin{tabular}{r|r|}
0 \\
16 \\
0
\end{tabular} & $\begin{array}{c}0 \\
14 \\
7.0\end{array}$ & $\begin{array}{c}3.1 \\
17 \\
2.9\end{array}$ & $\begin{array}{c}1.3 \\
24 \\
0\end{array}$ & $\begin{array}{c}1.3 \\
25 \\
5.0\end{array}$ & $\begin{array}{r}0 \\
16 \\
16\end{array}$ & $\begin{array}{r}0 \\
59 \\
98\end{array}$ & 8.7 & $\mid-\cdots$ & $\begin{array}{l}3 \mathbf{3} \\
\mathbf{1 1}\end{array}$ & $\begin{array}{l}0- \\
2.2\end{array}$ & $\begin{array}{c}18 \\
5.4\end{array}$ \\
\hline
\end{tabular}

\section{DISTRIBUTION IN BLOCKS OF COLUMNAR SAMPLES OF THE COAL BEDS}

The minor-element content of each block or of composites comprising several blocks of six columnar bed samples are shown in plate 1. These samples were selected with the intent to assemble a representative group of samples from the beds of this province. Some of the profiles show similarities for all the elements, and others are almost completely dissimilar. It may be assumed that samples from other beds would show a distribution of minor elements somewhere between these extremes. 
The most unusual columnar sample is ND-KR-Bu; in three com-: posites formed from the original 18 blocks of coal the degree of similarity between the profiles for each of the elements is unequaled by. the profiles for any other sample. The bottom block, which contained the largest amounts of the elements, also had the highest percentage of ash. A somewhat similar behavior by most of the elements is: found in ND-Cu-GC, although in this columnar sample the blocks in: the center of the bed contain the largest amounts of elements that: behave similarly; however, germanium, gallium, beryllium, yttrium, . and lanthanum have completely different types of profiles. In ND-. $\mathrm{BN}-\mathrm{N}$ a behavioral pattern similar to that in ND-Cu-GC is followed; with boron, titanium, vanadium, chromium, cobalt, and nickel showing a large degree of similarity in the patterns of their accumulation in the bed; to a smaller degree, beryllium, gallium, and yttrium also. show a similar relationship. Germanium was found only in the top block. Tin was not found in any of the blocks of this columnar sample. Large amounts of copper, unrelated to the amounts of the: other elements, were found in several small blocks. The distribution of lanthanum in the bed did not closely resemble that of any of the other elements.

Sample Mont- $\mathrm{K}_{2}-\mathrm{R}_{0}$ has a very heterogeneous mixture of patterns. Elements known to behave similarly do so in part of the bed, then. reverse their patterns in other parts. In Mont-S, a Cretaceous coal, a similarity of behavior is shown by groups of elements; in one group the distribution data on titanium, vanadium, chromium, and yttrium, and to a lesser degree, cobalt, molybdenum, and lanthanum follow similar patterns, and in another group the distribution data on beryllium, nickel, and gallium also have somewhat similar profiles. The data on boron, copper, germanium, and tin show no relationship between one group and another nor to any data on the other elements; some similarity may appear in the data on a few blocks, but not in the data on the greater part of the bed.

Sample Mont-AT, a Jurassic coal, is another example of heterogeneous accumulation of elements in coal. In adjacent blocks large differences in minor-element content are particularly noticeable, indicating that very little, if any, redistribution of the elements has taken place. Another factor that confirms the lack of redistribution and also indicates that the accumulation of most elements was syn-: genetic, is the gradual attainment of peaks or valleys in the element content shown in the profiles. This is especially shown by the five lowermost blocks of this sample (not including the carbonaceous shale at the bottom), in which the cobalt content gradually diminished upward. The sixth block has a very large cobalt content, which grad- 
ually diminishes through the next four blocks and then increases in successive blocks to the top of the bed.

The distribution of elements in the bed from which sample MontAT was taken and in some other beds could mean that a cyclic influx of material took place during deposition of the beds. This is further corroborated by a similar cyclic variation in the amount of ash from the coal of the beds. The varying amounts of ash could be a result of the fluctuations in the levels of the depositional basin or of the surrounding borderland, or both. It could also reflect a variation in rainfall and indicate changing stream channels and swamp drainage systems. The concentrations of minor elements in different blocks. of the same samples are controlled by these factors and many others, such as: types of rocks being weathered; rate of weathering and decomposition of different minerals; the chemical properties of the elements, and particularly the reactions while passing through solutions of differing pH's; ability to form, and stability and solubility of metalloorganic complexes of the elements; and biogenetic behavior of the elements in plants.

\section{DISTRIBUTION IN BEDS IN LOCAL AREAS}

The average minor-element contents of some of the beds are listed in table 9. The analyses are arranged in groups, with each group representing beds in the same general area. The data for the beds in each area are arranged in stratigraphic order. All the data are taken from channel or auger samples of whole beds, except data for samples. Mont-G-F and RB-F, which are weighted averages of blocks of columnar samples. One of the samples, Mont-GS-10501, which yielded 59.2 percent ash, cannot be considered coal but rather a carbonaceous shale.

The group of five samples from the Big Sandy field has some unusual characteristics not found in the other groups. The ratio of yttrium to lanthanum is persistently low compared to the other samples. The ratio of nickel to cobalt on an average is less than 2 if sample Mont$\mathrm{G}-\mathrm{F}$ is not considered. The concentrations of some of the elements appear to be diagnostic of a bed. Thus the higher and lower beds have much more titanium, chromium, and gallium, and slightly more vanadium, cobalt, and lanthanum than the three samples of the Flatness bed. If the abnormally high nickel content of sample MontG-F is discounted, nickel would also be in this group. The Flatness bed has more germanium than the other two beds. Molybdenum is almost evenly distributed. No pattern is shown by beryllium, boron, copper, and yttrium contents; the range for the concentrations of these four elements in the three samples of the Flatness bed is of the: same order as the range in the three beds. 


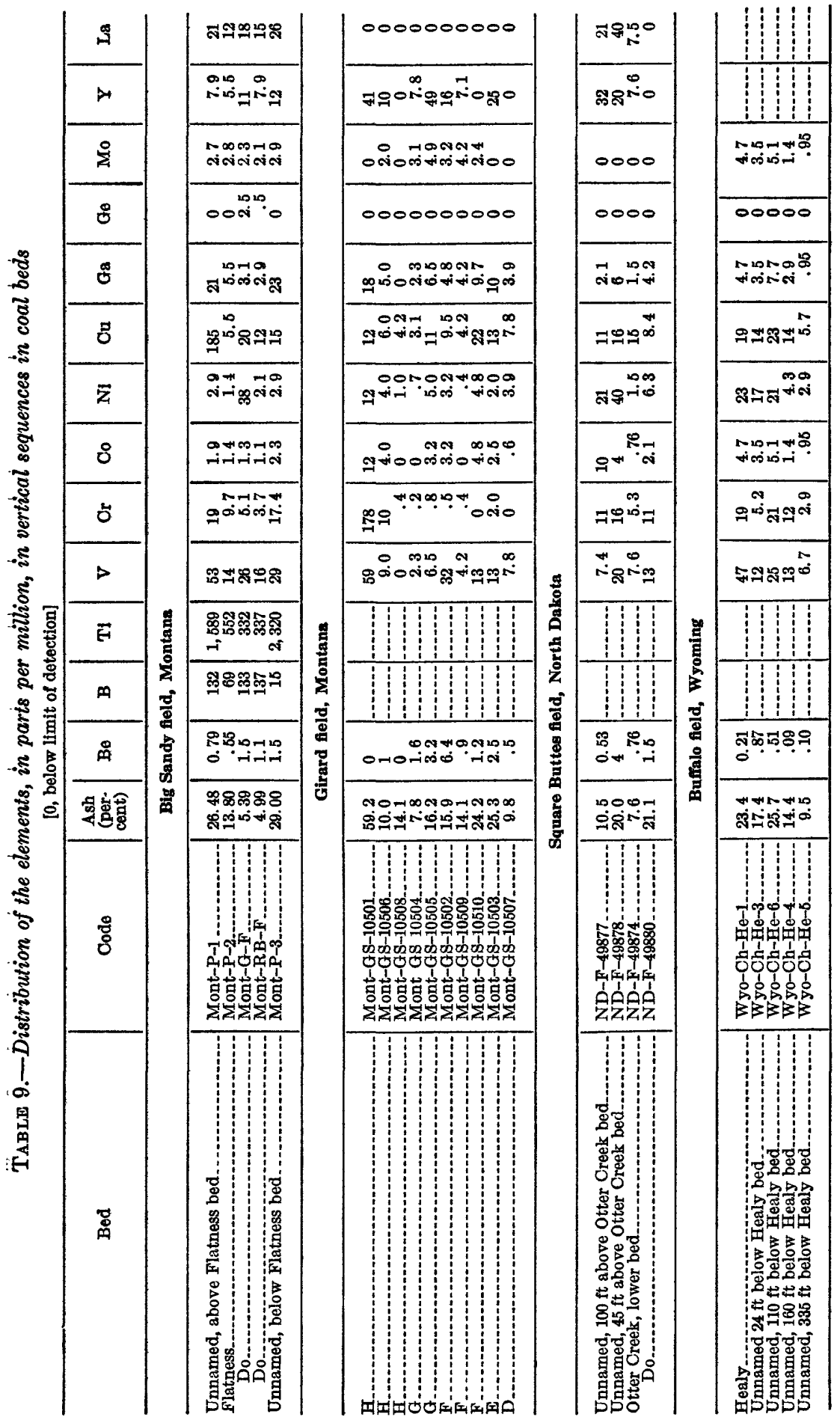


The group of samples from the Girard field, Montana, shows almost. a completely heterogeneous distribution of the elements. The ranges of contents in samples of the same bed, where several samples were taken is of the same order as that among the five different beds. Molybdenum seems to have an affinity for certain beds. The ratio of nickel to cobalt in the 10 samples is about $1: 1$. Seven samples contain considerable amounts of yttrium, whereas the lanthanum content. was below the detection limit in all the samples.

The group of samples from North Dakota lacks a pattern for the concentration of most of the elements. The content of nickel, cobalt, yttrium, and lanthanum seems to be greater in the upper beds; the ratio of nickel to cobalt is quite high, and in one sample it is 10:1. The average of the yttrium and lanthanum contents of the three beds gives a ratio of about $1: 1$.

In the group of samples from beds of the Buffalo field, Wyoming, the top beds seem to be enriched in all the elements, whereas the lowest amounts are found in the bottom bed. Germanium and tin were not found in any of the samples. The ratio of nickel to cobalt is $3: 1$ or higher for all these beds.

Probably some of the relations to which attention has been drawn, such as the ratios of nickel to cobalt and the persistent content of some of the elements in the various beds, would not change if additional samples were available. These distributions are probably the result of proximity to the source of elements and the proximity of the sample to drainage patterns in the swamps.

\section{DISTRIBUTION IN GROUPS OF BEDS IN DIFFERENT PARTS OF THE PROVINCE}

The deposition of coal beds in the province was not a continuous. process; because of their limited extent the beds cannot be traced for more than a few miles before they pinch out. As a result of this, a study cannot be made of the accumulation of the elements in the different parts of the basin by following the distribution pattern of a bed. Interpretations that have some significance can be obtained from averages of the analyses made of coals in groups of beds in limited areas. Table 10 gives the averages of 12 such groups, and their localities are plotted on figure 2. Beds at localities 1 and 2 are the Jurassic coals of the Lewiston and Great Falls fields. A single columnar sample of Cretaceous coal was taken from locality 3. At localities 4 through 14, all the coal beds are in the Tongue River member of the Fort Union formation; of these, particular notice is given to the averages for the beds at five localities, $4,5,8,9$, and 11-12, since theseaverages each include data for three or more beds. If the sedimentary 


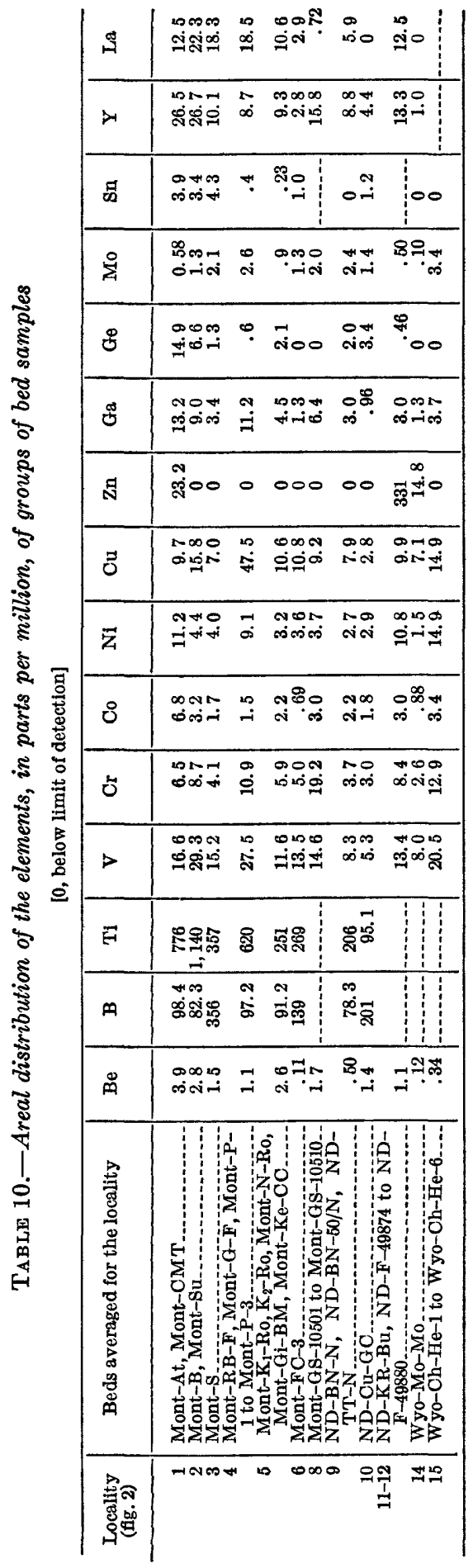


source was from the west and southwest during this period, then localities 4 and 5 are nearest the source, followed by 8, 9, and 11-12. Localities 6,10 , and 14 contain only one bed each and thus have little comparative value. The average for the group of beds at locality 15 includes the data on six Wasatch samples of the Buffalo field.

In the following discussion only the minor-element distribution in the Fort Union formation at five localities, $4,5,8,9$, and 11-12 is considered. The highest average content of beryllium was in the group of coal samples from locality 5 and the lowest in coal from locality 9 ; in general, coals of the western part of the province seem to contain more beryllium. The pattern for the data for boron is not clear. Coals definitely have been enriched in titanium nearer the source of sediments. Neither vanadium nor chromium content shows definite patterns; high and low contents were found in coal from both the eastern and western parts of the province. Coals of the eastern part of the province contained much more cobalt than those from the western part. Three of the averages for nickle range between 2.7 and $3.7 \mathrm{ppm}$. The samples from localities 4 and 11-12 had uncommonly high averages. In each of these there is one very high bed average, which, if excluded, would make the averages comparable to the other three. The ratios of nickel to cobalt, except for samples from locality 11-12, decrease in an eastward direction. Locality 11-12 is near the transcontinential arch and possibly during deposition some material was periodically carried into the basin from that direction. Copper seems to be distributed uniformly throughout the basin; although channel sample Mont-P-1 in locality 4 had an abnormally high content, the other four samples had an average content comparable with the average for other localities. Gallium content is slightly higher in the coals at three Montana localities, 4,5 , and 8 , than in the coals from two North Dakota localities, 9 and 11-12. Germanium, molybdenum, and tin show no preferential direction of enrichment. Yttrium content is lower in the western and lanthanum is generally lower in the eastern localities.

It is impossible to explain the distribution of most of the elements in the basin. The decrease of the ratios of nickel to cobalt in an eastward direction could be due to the preferential uptake of nickel over cobalt by plants. The change of the yttrium-lanthanum ratios could be due to two factors; in the western localities yttrium and lanthanum may be taken up by plants in proportion to the amount of these elements in the eroding source rocks, while in the eastern localities the stability of the organic complexes of these two elements may be the controlling mechanism. 


\section{RELATION OF THE MINOR-ELEMENT CONTENT OF COAL ASH AND POSSIBLE SOURCE ROCK}

In a developing peat bog the initial vegetation has its roots in the subsoil and primarily dependent upon this source for its nutrients. As the bog develops, subsequent vegetation has root systems in the peat from the preceding plants and few roots in the subsoil. The initial vegetation probably depletes the subsoil of its minor-element content and concentrates it in the humus formed by these plants. Subsequent plants thus receive a very small amount of minor elements from the subsoil and as the bog become thicker, none at all; rather, their minor-element content becomes dependent upon the release of the elements from the humus or upon the influx of the elements from weathering rocks on the borderland of the depositional basins.

Many of the coal beds have a high minor-element content in the lowest part of the beds that abruptly decrease toward the middle. This suggests that the elements were immobilized and were not available for accumulation by subsequent plant hife. Where the beds do have an increase or a uniform minor-element content throughout the bed, it must be assumed that another source of the elements became available: namely, an influx of these elements carried in solution into the coal depositional sites. Elements from this source would not only be subject to accumulation by plants, but also to other fixation processes of the swamps.

The minor-element content of coals is dependent, therefore, upon the weathering and erosion of rocks before and during the deposition of the coal beds. In the northern Great Plains coal province the period when the Fort Union formation especially the Tongue River member, was being deposited was also a period of prolific deposition of coals. Most of these coals were deposited in small isolated basins and probably deposition of organic debris was taken place in some part of the province in an almost continuous sequence. The beds thus yield an almost continuous sequence of the material from the the weathering rocks that contributed material to this cycle of deposition.

During Late Cretaceous and early Paleocene a Jarge outpouring of andesitic, dacitic, and some rhyolitic magmas took place along the western and southwestern margins of the basin. Much of this material later contributed to the deposits of Fort Union age. Bentonitic beds in this formation indicate contemporaneous vulcanism. That such conditions existed is concluded by Woolsey and others (1917, p. 25); Knappen and Moulton (1930, p. 48-50); Dobbin (1930, p. 1421); Stow (1946); McMannis (1957); in addition, the orogenic sequence of events is summarized by Eardley (1951, chap. 19-22).

Figure 3 presents a comparison of the minor-element contents of various rock types with those of the coals of this province and of 
COALS OF NORTHERN GREAT PLiATNS COAL PROVINCE A-41
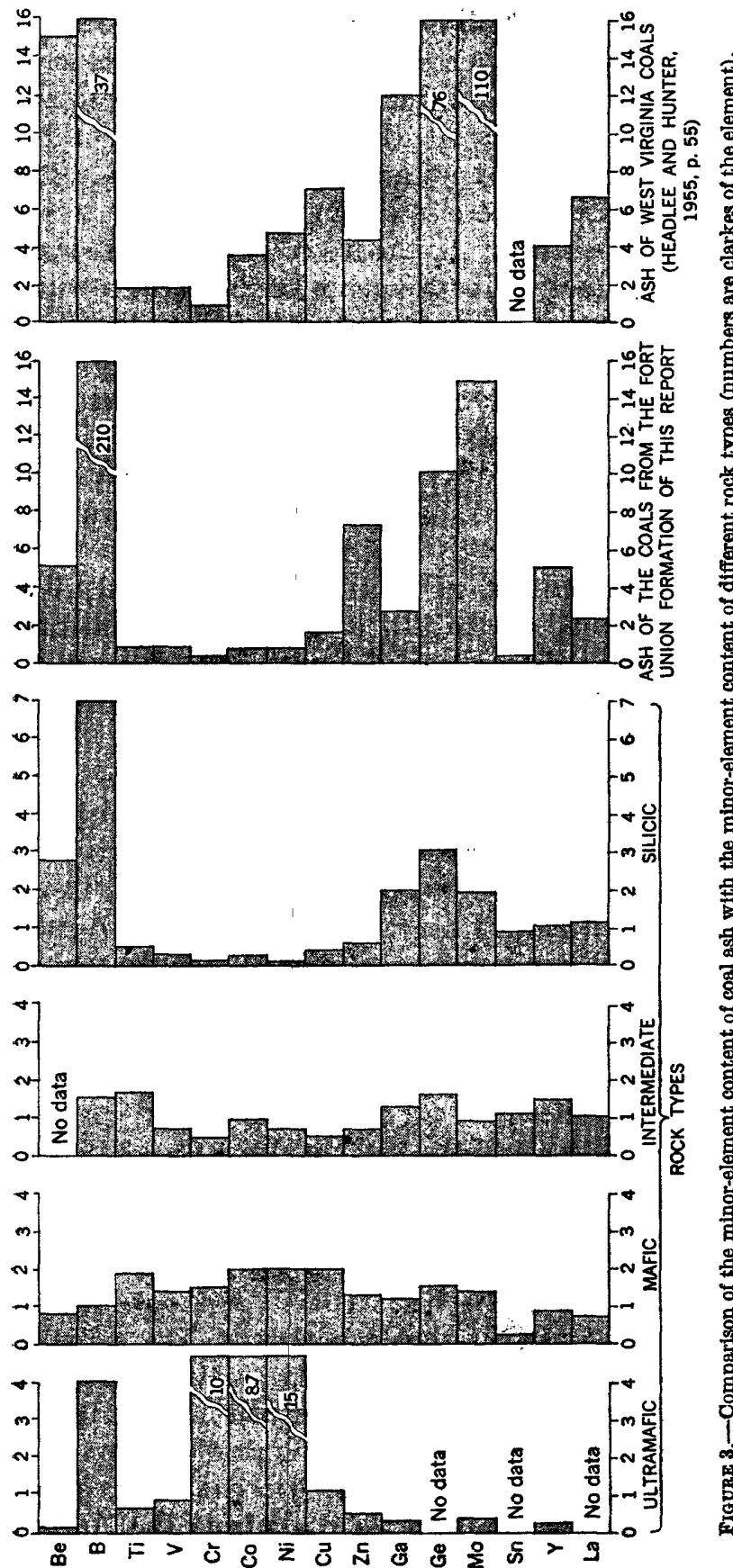
West Virginia. Most of the data for the minor-element content of the various rock types are those of Vinogradov $(1956$, p. 49-50). The data for boron in silicic rocks was supplied by R. R. Coats (written communication, 1956). The length of the bar for each of the elements found in each of the rock types and coal ash that are represented in the figure is the ratio of the element in these samples to the average abundance of the element in the earth's crust. Because the values for the average abundance of the elements in the earth's crust were obtained from a number of different sources but those for the rock types are from one compiled source, discrepancies appear. The elements that show the largest discrepancies are boron, gallium, germanium, and yttrium. The boron discrepancy is caused by the use of Coats' content for boron in rhyolites of Montana; that for gallium, germanium, and yttrium is the result of some rather high content for thoseelements used by Vinogradov.

The profiles in figure 3 show a remarkable similarity between the minor-element content of the ash of Fort Union coal samples and that of silicic rocks. Boron, molybdenum, and zinc are proportionally much higher than the other elements, but they are biogenetic elements and nore of them may be expected in coal. The source of the extremely large amount of boron can be attributed to the volcanic ash eruptions that were probably prevalent during this time. The high zinc content in the ash includes the seven very high values for zinc in samples from Oliver County, N. Dak. These samples. could have been enriched by a secondary influx of zinc into the coals after deposition. The minor-element contents of the coal ashes show Jess agreement with the contents of the intermediate rocks, and practically not at all with the contents of the more mafic rocks.

The data of Headlee and Hunter (1955, p. 55) are also plotted on figure 3 , and a difference is noted between the minor-element content of the coal ash of samples from the Northern Great Plains province and those of coal samples from West Virginia. The beryllium, boron, gallium, germanium, and molybdenum contents of the latter ash samples are in closer agreement with their content in silicic rocks. The distribution of the rest of the elements more closely conforms to the distribution found in intermediate rocks. The larger amount of beryllium in the West Virginia coal could be attributed to the beryllium-rich pegmatites on the Piedmont, which may be indicative that this source area for sediments was a beryllium-rich petrographic province. It is noteworthy that the boron content is much lower in the West Virginia coal ashes than in the coals from the Northern Great Plains province. It is not possible, at present, to explain the high germanium and molybdenum content in the West Virginia coal ash. 
If the source rock for the elements in the coal bed was predominantly of one type, the amount of each element in this rock certainly should be directly reflected by the amount in the coal or in its ash. If more than one type of rock contributed material to a coal basin, it may be possible to identify the types if a large enough group of elements is used for the evaluation. The preceding discussion refers only to the 15 minor elements considered in this report. It is well known that certain elements, such as sodium, potassium, magnesium, and others, are definitly lost during the coalification process and any interpretations of the conclusions of this report should not include any elements except those whose geochemistry was investigated for this report.

\section{COMPARISON OF THE A VERAGE MINOR-ELEMENT CONTENT OF THE COAL WITH THAT OF LIVING PLANTS}

In the preceding section it was suggested that there is a relation between the minor-element content of the coal and of the type of source rocks that contributed sediments to the coal depositional sites. This observation is based on the assumption that no great change has taken place in the minor-element content of the coal since its burial. There is no way of proving this; however, analogies can be made by examining the minor-element content of present day plants. It must be kept in mind that the minor-element content in coal is a product of a number of fixation processes, not just of plant accumulation, and any comparison between plants and coal should not be expected to agree for all the elements. This was pointed out by Goldschmidt (1935, p. 1102).

Plants accumulate certain elements in proportion to the abundance and availability of the elements in the soils. This fact is the basis of biogeochemical prospecting methods. Data from investigations show that plants have a wide range of tolerance for some elements. There are a number of elements, of course, which are toxic to plants. Data from Warren and others $(1953$, p. 74) for molybdenum, from Warren and others (1951, p. 919-930) for copper and zinc, and from Warren and Delavault (1954, p. 71-72) for nickel are presented in table 11 and show the range of accumulation of these elements in various parts of plants growing in mineralized areas. Other data (table 12) such as that from Robinson and Edgington (1945, p. 16-26) predominantly on agricultural crops, from Robinson and others (1958) on rare earths in hickory leaves, from Cannon (1955, p. 132) on zinc in swamp plants in a zinc mineralized area, and from Salmi (1955, p. 9-11) on titanium, vanadium, chronium, cobalt, nickel, copper, zinc, and molybdenum in leaves and twigs of Ledlum 
palustre growing in a peat bog over a mineralized sulfide zone, show that large amounts of some elements can be accumulated by plants. Most of the above analyses are of unusual plants or of plants growing in unusual environments. A series of analyses by the Geological Survey of parts of trees growing in a sandy soil derived from Cretaceous sediments of the Atlantic Coastal Plain (table 12, column 2) show some interesting relations with the coal averages. The data on the contents of titanium, vanadium, chromium, nickel, copper, and tin in the parts of trees agree very well with the data for coal; the amounts of beryllium, boron, cobalt, zinc, gallium, germanium, molybdenum, vanadium, and lanthanum are small in the trees. Boron in the trees is low compared to that in the coal; however, the data on boron in other plants agree well with the data for coal.

The Rocky Mountains are considered to be a boron-rich petrographic province, and large amounts of the element can be expected to be found in the coal. Cobalt control is not usually low but as the ratio of nickel to cobalt is about $10: 1$, it does show that tree components do accumulate more nickel than cobalt. A high ratio of nickel to cobalt is also reported by Salmi. The value for the zinc content in trees is in agreement with the value given by Warren and others, but much lower than that for the coal. However, because the value given for coai includes several very large amounts of zinc found in a small part of the basin, the average value for the average coal of the basin is probably too high. The values for the amounts of gallium, germanium, molybdenum, yttrium, and lanthanum found in the trees are too low. No additional data on gallium and germanium in plants are available; however, for molybdenum, yttrium, and lanthanum there are sufficient data to show that our values are among the lowest. In this comparison of the minor-element content of coals and plants only one method of accumulation has been considered, whereas other processes, as mentioned earlier, also add to the amounts of the elements is the coals. Beryllium, which is particularly toxic to plants, especially in an acid environment (Hoagland, 1952), can be considered to be emplaced by the formation of metallorganic complexes; this has been discussed thoroughly by Stadnichenko and others (1961). Other elements that can be considered partly to be emplaced in the coal swamps by this process are those that form very stable complexes, such as vanadium, chromium, cobalt, nickel, copper, molybdenum, and probably gallium, germanium, yttrium, and lanthanum.

Goldschmidt (1935, p. 1102) found that beryllium, vanadium, cobalt, nickel, gallium, zinc, and yttrium were more abundant in the ash of forest humus than in plant ash. This probably is also the case for swamp humus and could be the result of the formation of complexes 


\section{COALS OF NORTHERN GREAT PLAINS COAL PROVINCE A-45}

TABLE 11.-Range of accumulation of copper, zinc, molybdenum, and nickel in parts of plants in mineralized areas

[Mineral contents in parts per million]

Copper and zinc in dry plants

[Warren and others, 1951, p. 920-923]

\begin{tabular}{|c|c|c|c|c|c|c|c|c|c|c|}
\hline \multirow{2}{*}{ Place of growth } & \multicolumn{2}{|c|}{$\begin{array}{c}\text { California } \\
\text { poppy }\end{array}$} & \multicolumn{2}{|c|}{ Paloverde } & \multicolumn{2}{|c|}{ Creosote bush } & \multicolumn{2}{|c|}{ Scrub oak } & \multicolumn{2}{|c|}{ Ocotillo } \\
\hline & $\mathrm{Cu}$ & $\mathrm{Zn}$ & $\mathrm{Cu}$ & $\mathbf{Z n}$ & $\mathrm{Cu}$ & $\mathrm{Zn}$ & $\mathbf{C u}$ & $\mathrm{Zn}$ & $\mathrm{Cu}$ & $\mathrm{Zn}$ \\
\hline $\begin{array}{l}\text { Above oxidized } \\
\text { zone }\end{array}$ & $32-75$ & $50-66$ & $11-30$ & $14-19$ & $27-41$ & $17-28$ & $15-42$ & $20-40$ & $14-26$ & $18-40^{\circ}$ \\
\hline zone. & $11-12$ & $63-153$ & 3-7 & $10-40$ & $3-27$ & $16-54$ & $6-9$ & $14-23$ & $9-25$ & $15-23$ \\
\hline
\end{tabular}

Molybdenum in needles tips and twigg

[Warren and others, 1953, p. 74]

\begin{tabular}{|c|c|c|c|}
\hline Place of growth & Alpine fir & $\underset{\text { pine }}{\text { Lodgepole }}$ & $\begin{array}{c}\text { Oreosote } \\
\text { bush }\end{array}$ \\
\hline $\begin{array}{l}\text { A prospect. } \\
\text { Areas of minor mineralization } \\
\text { Remote from mineralization. }\end{array}$ & $\begin{array}{r}43-65 \\
2-5 \\
0.1-0.3\end{array}$ & $2-3$ & \\
\hline
\end{tabular}

Nickel in stems, needles, tips, and leaves

[Warren and Delavault, 1954, p. 71-72]

\begin{tabular}{|c|c|c|c|c|c|c|c|c|c|}
\hline \multirow{3}{*}{ Place of growth } & \multicolumn{2}{|c|}{$\begin{array}{l}\text { Mountain hem- } \\
\text { lock }\end{array}$} & \multicolumn{2}{|c|}{ Mountain fir } & \multicolumn{5}{|c|}{ Western redcedar } \\
\hline & \multirow{2}{*}{$\begin{array}{c}\text { Stems } \\
(1-5 \mathrm{yr})\end{array}$} & \multirow{2}{*}{ Needles } & \multirow{2}{*}{$\begin{array}{l}\text { Stems } \\
(1-5 \mathrm{yr})\end{array}$} & \multirow{2}{*}{ Needles } & \multirow{2}{*}{ Tips } & \multicolumn{3}{|c|}{ Stem } & \multirow{2}{*}{ Leaves } \\
\hline & & & & & & $3 \mathbf{y r}$ & $4-5 \mathrm{yr}$ & older & \\
\hline $\begin{array}{l}\text { Above deposits. } \\
\text { Remote from mineraliza- } \\
\text { tion. }\end{array}$ & $\begin{array}{l}5 \\
0.2-0.6\end{array}$ & 8 & $15-26$ & $\begin{array}{l}21-24 \\
1-0.4\end{array}$ & 36 & 20 & 28 & 4 & $\begin{array}{l}32^{*} \\
1.5\end{array}$ \\
\hline
\end{tabular}

TABLE 12.-Comparison of the minor-element content, in parts per million, of the coals of the Northern Great Plains province with that of some plants

[0, below limit of detection]

\begin{tabular}{|c|c|c|c|c|c|c|}
\hline Elements & Coal & $\begin{array}{l}\text { Trees } \\
\text { (U.S. } \\
\text { Crool. } \\
\text { Survey) }\end{array}$ & $\begin{array}{l}\text { Plants } \\
\text { (Salmi, } \\
\text { I955) }\end{array}$ & $\begin{array}{c}\text { Plants } \\
\text { (Cannon, } \\
\text { 1955) }\end{array}$ & $\begin{array}{c}\text { Hickory } \\
\text { leaves } \\
\text { (Robinson } \\
\text { and others, } \\
\text { 1958) }\end{array}$ & $\begin{array}{c}\text { Crops and plants } \\
\text { (Robinson and } \\
\text { Edgington, 1945) }\end{array}$ \\
\hline 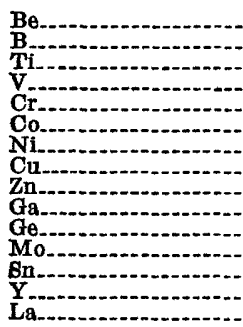 & $\begin{array}{r}2.4 \\
112 \\
476 \\
20.1 \\
9.3 \\
2.8 \\
8.6 \\
17.4 \\
107 \\
6.3 \\
2.9 \\
2.1 \\
2.1 \\
17.4 \\
14.7\end{array}$ & $\begin{array}{c}0.1 \\
16.6 \\
374 \\
15 \\
7.5 \\
.7 \\
7.1 \\
12.3 \\
37.4 \\
.6 \\
0 \\
0 \\
1.7 \\
3 \\
4\end{array}$ & $\begin{array}{c}109 \\
0 \\
0 \\
3.3 \\
0 \\
25 \\
75 \\
136 \\
.7 \\
\\
\\
\end{array}$ & 10,000 & \begin{tabular}{|r} 
\\
\\
\end{tabular} & $\begin{array}{r}70>3,000 \\
\begin{array}{r}20 \\
144.5>2,000\end{array} \\
9>300\end{array}$ \\
\hline
\end{tabular}

1 For rare earth group. 
of these elements. A discussion of this process is carried on further in the next section.

In summation, the minor-element content of the coal is in accord with that accumulated by plants and plant debris. In the previous section it was shown that the minor-element content of the coal is related to the minor-element content of the type of source rocks contributing material to the coal-forming swamps. From this it follows that little, if any, change has taken place in the amount of the 15 minor elements in the coal since the time of deposition to the present. In the coalification process a large amount of organic material is lost during its transformation into coal. There probably is also a concomitant loss of minor elements associated with this loss of material.

\section{SPECIAL SAMPLES}

Special samples such as coalified logs and kettle-bottom coal are treated separately because they offer a basis for more intense speculation about the accumulation of minor elements in coal. There is a general similarity between these samples and the isolated coalified logs found in the Cretaceous sediments of the Atlantic Coastal Plain (Stadnichenko and others, 1953, p. 15). Their minor-element content is similar in many respects, and their coalification has a genetic relationship. Data are given in tables.

The kettle-bottom coal is taken from partly coalified and sedimentfilled upright tree stumps found above the coal beds. These stumps generally fall out when the underlying coal is mined out. The shape of the cavity resulted in their being called kettle bottoms or cauldrons. The bottom of such stumps is in contact with the coal bed and the upper part is buried in sandstone or shale. The coalified trees are logs, branches, and leaf imprints of fallen trees lying horizontally and sometimes found as high as two feet above the coal bed. Only the main parts of large logs were collected but the designation "trees" was used during the collection to indicate that smaller units of the trees were present other than just the main trunk. These also are enclosed in shale or sandstone. In the coalified trees there is evidence of the compression and loss undergone by woody material after burial and during coalification. Several such tree trunks were very long (more than 20 feet), about 1 to 2 feet wide, but only $1 / 2$ to 1 inch thick. The tree trunks had lenslike cross sections indicating that a round log during its coalification degenesis was reduced by about a 24:1 volume ratio. The specific gravity of these coals is about 1.2 to 1.3 , and that of the living trees is about 0.5 to 0.7 This is only about a twofold increase in the specific gravity, indicating that only about 1 part in 12 remains of the original plant material. As a result of this, large quantities of humic and perhaps amino acids would be available 
to react with metal ions or complexes passing through the degenerating logs to form metallo-organic complexes.

These kettle-bottom coals and coalified trees were not coalified in the same way as the trees that were laid down in the swamp, although their coal is probably of the same rank as the coal of the beds, and the degree of overall coalification was probably similar. Plant structures in these types of samples are usually much better preserved than in any of the coal bed samples. This indicates less degeneration of plant tissues in the kettle-bottom coals and trees than in trees coalified in the swamp environment. Degradation of the celluloses and proteins certainly took place to form humic acid, but the rate was probably much slower than under swamp conditions. These trees were enclosed by inorganic sedimentary material more rapidly than the organic debris of the coal swamp. As a result of this, bacterial action was reduced, and the $\mathrm{pH}$ was probably higher. The slower decomposition and the enclosed environment probably produced better conditions for the retention of the elements already in plant tissues and also for the greater absorption of and reaction with metallic ions or complexes in solutions passing through the buried logs. Their enclosure in clastic materials suggests that they were buried at a time when large amounts of clastic material and material in solution were being brought into the depositional basins.

The minor-element content of these samples has no direct relation to that of the coal beds. Table 13 gives the amount of the element in parts per million in coal of the kettle-bottom coals and coalified trees and of the associated beds. If more than one kettle-bottom coal was analyzed, the figures are the average. Table 14 presents the ratios of the elements in the kettle-bottom coals and coalified trees to those in the beds.

TABLE 13.-Comparison of the minor-element content of kettle-bottom coals ( $K B)$ and coalified trees (Tr) with the associated coal beds

[In parts per million in coal]

\begin{tabular}{|c|c|c|c|c|c|c|c|c|c|c|c|}
\hline \multirow{2}{*}{ Element } & \multicolumn{2}{|c|}{ Mont-Su } & \multicolumn{2}{|c|}{ Mont-RB-F } & \multicolumn{2}{|c|}{ Mont-N-RO } & \multicolumn{3}{|c|}{ Mont-K-Ro } & \multicolumn{2}{|c|}{ Mont-Gi-BM } \\
\hline & $\mathbf{K B}$ & Bed & $\mathbf{T r}$ & Bed & $\mathbf{K B}$ & Bed & $\mathbf{K B}$ & $\operatorname{Tr}$ & Bed & $\mathbf{T r}$ & Bed \\
\hline $\begin{array}{l}\mathrm{Be} \\
\mathrm{B} \\
\mathrm{Ti} \\
\mathrm{T} \\
\mathrm{C} \\
\mathrm{Cr} \\
\mathrm{Co} \\
\mathrm{Ni} \\
\mathrm{Cu} \\
\mathrm{Cu}\end{array}$ & $\begin{array}{c}1.8 \\
17.1 \\
551 \\
323 \\
22.8 \\
1.2 \\
2.3 \\
5.7 \\
0 \\
60.8 \\
20.0 \\
4.8 \\
26.6 \\
11.6 \\
1.3\end{array}$ & $\begin{array}{r}3.8 \\
118 \\
1,350 \\
30.4 \\
9.4 \\
3.8 \\
5.4 \\
10.3 \\
0 \\
7.7 \\
5.9 \\
1.8 \\
5.6 \\
24.2 \\
11.1\end{array}$ & $\begin{array}{c}1.2 \\
30.0 \\
832 \\
325 \\
158 \\
16.6 \\
24.1 \\
9.2 \\
0 \\
18.3 \\
37.4 \\
4.2 \\
0 \\
16.6 \\
5.8\end{array}$ & $\begin{array}{c}1.1 \\
137 \\
337 \\
16.1 \\
3.7 \\
1.1 \\
2.1 \\
11.6 \\
0 \\
2.9 \\
.5 \\
2.1 \\
.49 \\
7.9 \\
15.0\end{array}$ & $\begin{array}{r}3.0 \\
35.0 \\
96.6 \\
142 \\
53.3 \\
3.8 \\
7.7 \\
4.6 \\
0 \\
19.2 \\
84.8 \\
1.2 \\
2.2 \\
31.4 \\
3.6\end{array}$ & $\begin{array}{c}8.2 \\
21.0 \\
288 \\
17.1 \\
14.3 \\
3.0 \\
2.8 \\
13.3 \\
0 \\
9.3 \\
6.5 \\
.78 \\
0.9 \\
31.2 \\
9.7\end{array}$ & $\begin{array}{r}6.9 \\
14.0 \\
743 \\
283 \\
81.7 \\
3.8 \\
6.9 \\
8.5 \\
0 \\
20.3 \\
819 \\
4.2 \\
0 \\
34.7 \\
3.3\end{array}$ & $\begin{array}{r}3.9 \\
6.2 \\
846 \\
250 \\
84.9 \\
6.3 \\
15.4 \\
9.6 \\
0 \\
12.5 \\
184 \\
4.4 \\
2.0 \\
26.2 \\
3.9\end{array}$ & $\begin{array}{c}1.1 \\
167 \\
197 \\
9.3 \\
4.7 \\
1.7 \\
3.4 \\
8.7 \\
0 \\
4.1 \\
1.5 \\
.75 \\
.37 \\
2.7 \\
13.3\end{array}$ & $\begin{array}{c}5.8 \\
42.8 \\
151 \\
35.4 \\
12.6 \\
10.1 \\
10.1 \\
12.6 \\
0 \\
6.6 \\
5.3 \\
.50 \\
0 \\
30.3 \\
5.0\end{array}$ & $\begin{array}{r}1.2 \\
76.9 \\
370 \\
16.8 \\
3.0 \\
1.0 \\
2.1 \\
16.6 \\
0 \\
2.9 \\
.10 \\
.55 \\
.55 \\
5.3 \\
12.4\end{array}$ \\
\hline
\end{tabular}


TABLE 14.-Ratios of the minor-element content of the kettle-bottom coals and coalified trees to that in the associated beds

\begin{tabular}{|c|c|c|c|c|c|c|}
\hline \multirow{2}{*}{ Element } & \multirow{2}{*}{$\underset{(\mathrm{K} B)}{\text { Mont-Su }}$} & \multirow{2}{*}{$\begin{array}{l}\text { Mont- } \\
\text { RB-F } \\
\text { (Tr) }\end{array}$} & \multirow{2}{*}{$\begin{array}{l}\text { Mont- } \\
\text { N-Ro } \\
\text { (KB) }\end{array}$} & \multicolumn{2}{|c|}{ Mont-K-Ro } & \multirow{2}{*}{$\underset{(\mathbf{T r})}{\substack{\text { Mont- } \\
\text { Gi-BM }}}$} \\
\hline & & & & $\mathrm{KB}$ & $\mathrm{Tr}$ & \\
\hline $\begin{array}{l}\mathrm{B} \\
\mathrm{B}\end{array}$ & $\begin{array}{r}0.48 \\
.15 \\
.41 \\
10.6 \\
2.4 \\
.32 \\
.43 \\
.55 \\
7.9 \\
3.4 \\
2.7\end{array}$ & $\begin{aligned} & 1 . 1 \\
& 2.22 \\
& 20 . \\
& 42 . \\
& 15.1 \\
& 11.5 \\
& 6.79 \\
& 64.8 \\
& 74.0\end{aligned}$ & $\begin{array}{l}0.37 \\
1.7 \\
.34 \\
8.3 \\
3.7 \\
1.3 \\
2.8 \\
.35 \\
2.1 \\
13.0 \\
1.5\end{array}$ & $\begin{aligned} & 6 . 3 \\
& .08 \\
& 3.8 \\
& 30.4 \\
& 17.4 \\
& 2.2 \\
& 2.0 \\
& 5.98 \\
& 54 \\
& 546.6\end{aligned}$ & $\begin{array}{r}\text { 3. } 5 \\
.04 \\
4.3 \\
26.9 \\
18.1 \\
3.7 \\
4.5 \\
1.1 \\
3.0 \\
123 \\
5.9\end{array}$ & $\begin{aligned} 4.8 \\
.56 \\
.41 \\
2.1 \\
4.2 \\
10.1 \\
4.8 \\
.76 \\
2.3 \\
53.0 \\
.91\end{aligned}$ \\
\hline $\begin{array}{l}\text { Y } \\
\text { La }\end{array}$ & $\begin{array}{l}4.8 \\
.48 \\
.12\end{array}$ & $\begin{array}{l}2.1 \\
.39\end{array}$ & $\begin{array}{l}1.0 \\
.37\end{array}$ & $\begin{array}{r}12.9 \\
.25\end{array}$ & $\begin{array}{l}0.4 \\
9.7 \\
.29\end{array}$ & $\begin{array}{l}5.7 \\
.40\end{array}$ \\
\hline
\end{tabular}

The approximate order of abundance for the elements in the kettlebottom coals and coalified trees in relation to the beds above which these samples were found is $\mathrm{Ge}>\mathrm{V}>\mathrm{Cr}>\mathrm{Ga}>\mathrm{Co}, \mathrm{Ni}, \mathrm{Y}>\mathrm{Mo}, \mathrm{Be}$, $\mathrm{Ti}, \mathrm{Sn}>\mathrm{Cu}>\mathrm{La}>\mathrm{B}$ (tables 13 and 14). The first four of these elements are very highly concentrated in the kettle-bottom coals and coalified trees as compared to the beds. The next seven are less concentrated in the kettle-bottom coals and coalfied trees as compared to the beds, whereas the last three elements are depleted in the kettlebottom coals and coalified trees. Thus boron, which is most highly concentrated in the beds, is the least concentrated in the special samples; chromium, which is least concentrated in the beds, is among the more abundant elements in the kettle-bottom coals and coalified trees. There is a similar reversal for vanadium and several other elements.

Except for vanadium, chromium, gallium, and germanium, the element content of the kettle-bottom coals and coalified trees is not higher than that in many plants. Germanium and gallium are not toxic to plants; so it is possible for plants to have large accumulations of these metals. Vanadium is known to be concentrated highly in the ash of some crude oils and in some organisms in the sea; like chromium, however, it is quite toxic to most plants. Some selective plant types can grow in chromium-rich soils, but kettle-bottom coals and coalified trees are not formed from these types of plants.

The element content of the vitrain samples, many of which are the remains of trees buried in the peat of the coal swamp, is similar to the blocks of coal from which they come. Two elements are an exception-the amount of germanium is usually much higher, and lanthanum is much lower in vitrain. The content of these two elements 
in the vitrain particularly, bear a similarity to their content is kettlebottom coals and coalified trees. The coalification process that produced vitrain can be considered to be intermediate between the least and most intense processes of plant decomposition. This suggests that rate of degradation as well as the enviroment of deposition was responsible for the retention of elements already present in the plants or for the accumulation during and after burial.

The most probable method by which the amount of the minor elements now found in the kettle-bottom coals and coalified trees was controlled was the formation of metallo-organic complexes. The elements forming these complexes could be either those accumulated by the plant at the time of growth, or those acquired by the reaction of the elements carried in solution that passed through the degenerating plant tissues. To assess this means of acquisition of the minor elements, we examined several groups of elements for the stability of their organic complexes. Data for the provincial averages for the beds (table 6) show the ratio of yttrium to lanthanum to be almost $1: 1$. This is approximately the same as the ratio for all the beds listed in table 13 , which is $1.2: 1$. The average contents of the kettle-bottom coals and coalified trees is yttrium, $25 \mathrm{ppm}$, and lanthanum, $3.8 \mathrm{ppm}$, or a ratio of about $6: 1$ to $7: 1$. It is obvious then that kettle-bottom coals and coalfied trees are enriched in yttrium and depleted in lanthanum as compared to the beds. Little can be said of the plant content of these elements as there is no way of knowing what the original content was, but it is known that parts of some plants can concentrate much larger quantities of these elements than are found in the kettle-bottom coals and coalified trees.

The stability constants of some yttrium and lanthanum organic complexes are as follows: Martell and Calvin (1952, p. 196) give the stability of rare earth chelates as yttrium greater than lanthanum. Vickery (1953, p. 84) lists Schwarzenbach's figures for the stability constants of lanthanon amino acid complexes; in the four cases listed, the stability constants of yttrium are much greater than lanthanum. The solubilities of these complexes are unknown; however it can be assumed that they are related to the stability constants, that is, the elements that form more stable metallo-organic complexes would also form more insoluble complexes.

The above relation suggests that the two elements were either introduced from solutions passing through the kettle-bottom coals or coalified trees and that yttrium, owing to the higher stability of its complexes, was selectively added to the kettle-bottom coals and coalified trees and that more lanthanum was selectively leached out from the original yttrium-lanthanum content accumulated during the growth of the trees. Without more knowledge about the content of 
these two elements in the original plant material, or in similar plants: now growing in a similar environment, little more can be said.

Another group of elements to be considered in a similar way are copper, nickel, and cobalt. In the samples of blocks of coal and in the averages for the bed their relationship is usually copper more abundant than nickel, which is more abundant than cobalt; furthermore, in the averages for the province the clarke of copper is much larger than those of nickel or cobalt. In the beds listed in table 13, the copper content is highest, followed by nickel, then cobalt. In the special samples, however, the nickel content is highest in three of the beds, while the copper content is highest in the other three beds. The greater amount of cobalt in the special samples is significant when compared with the contents of the associated beds; when the ratios of copper, nickel, and cobalt contents are considered (table 14), cobalt shows the highest ratios, with nickel next, and then copper. Nickel and cobalt increase in all but one set, whereas the copper content decreases in all but one set. Thus some copper was lost, and the amount of nickel and cobalt increased in the kettle-bottom coals and coalified trees.

Martell and Calvin (1952, p. 189 and other pages) show that the copper complexes are most stable, and those of nickel and cobalt. much less stable in that order, for bivalent states only. This, of course, is the opposite of yttrium and lanthanum whose metal complexes with higher stability are more concentrated in kettle-bottom coals and coalified trees.

However, these three elements are biogenetic and probably form very complex metallo-organic compounds in plants. If they formed the same type of complex, the stability constants should show the same relationship as that expressed by yttrium and lanthanum. Cobalt is known to form the very complex vitamin B-12, and nickel forms a very stable nickel-porphyrin. It is possible that the copper ions are reduced to $\mathrm{Cu}^{+}$thus not permitting the stability relation that these three elements would have if their valences and the donor groups remain identical.

The enrichment of germanium, chromium, and vanadium in the kettle-bottom coals and coalified trees as compared to bedded coal can also be considered as to their stabilities in complex formation. Martell and Calvin (1952, p. 234-235) make three statements which are pertinent:

1. For complexes of the 'outer-orbital' type there is no sharp discontinuity in rates, but rather a gradual decrease in lability as the charge on the central (metal) ion increases. . . .

2. This decrease in lability is due in part to the increasing covalent character of the bonds in the complex ions. 
3. Central metal ions which form more covalent bonds with ligands are usually assumed to form stable complexes. There can be no doubt that covalent character is an important-probably the most important-factor in determining stability.

The large amounts of vanadium, chromium, gallium, and germanium in the kettle-bottom coals and coalified trees could be the result. of either accumulation by plants during growth or by some secondary postdepositional process. There is a possibility that during the degeneration of the plants after burial these four elements were not lost, but were retained in the organic matter of the coal. Then the concentration of these elements would be tenfold, which is about the right magnitude. This would assume that these four highly concentrated elements are held most firmly by adsorption or form the most stable and least soluble organic complexes. It is also possible that these elements were introduced from solutions passing through the buried logs and were emplaced in the forming coal. Again as in the previous suggestion, these elements would have to be firmly adsorbed or form the most stable and insoluble complexes of the 15 elements.

From the foregoing, the most probable explanation for the extremely low content of vanadium and chromium in the coal beds and the high concentration in the kettle-bottom coals and coalified trees is that the reducing conditions in the swamps were much stronger than in sediments in which the kettle-bottom coals and coalified trees were formed. It is probable that in the coal swamp vanadium, chromium, and germanium were reduced to their lowest valence states and as a result the stability of any complexes formed would be low. In the kettle-bottom coals and coalified trees this lower valency state is never reached; the original amount of the elements in the original plant material could be retained; and any elements in a higher valency state that were brought in by solutions would have tended to form relatively inert complexes. This in no way contradicts our earlier conclusions of a general low availability of vanadium and chromium in the province. The enclosure of these trees in the sediments occurred at a time of increased erosion of the source rocks; new sources of these two elements were made available, especially because these elements are found in minerals that weather rapidly. The amount of this type of coal is very small, and only small amounts of an element are necessary to produce the high concentrations found in the kettlebottom coals and coalified trees. The content of these elements in the beds still remained very low despite the fact that the kettlebottom coals were enriched. Finally, if any large amount of chromium had been introduced into the coal bed at any time, it should have been precipitated as the very insoluble hydroxide. This is also true if 
it were released from a complex in decaying plants in the coal swamp. The suggested difference in the redox potential may also account for the higher cobalt content of the kettle-bottom coals and coalified trees. Trivalent cobalt forms very insoluble hydroxides in an acidic aqueous environment, however, whether or not this is what happens is uncertain. The differences in redox potential could be the reason why, in individual coalified logs and thin coal beds, a number of elements are found in much higher concentrations than in thick coal beds.

The reason for the low boron content in the kettle-bottom coals and coalified trees is unknown. Boron forms esters, but if this is the reason for the consistently lower content in the special samples and the higher content in the beds, the mechanism which does it is unknown at present.

Goldschmidt (1935, p. 1102) indicates that boron is lost from forest humus upon decay of the plant material. He did not mention copper and lanthanum in the group in which the humus is enriched and whether an analysis was made for these elements. If these two elements are also lost from the forest litter, then this type of minorelement loss is analogous to that found in the kettle-bottom coals and coalified trees. The difference in the redox potential, the concomitant valency states, and the resulting stability of any complexes which may be formed are the principal reasons why the minorelement contents of the kettle-bottom coals and coalified trees as well as of the forest humus, differ from contents of a coal bed formed by the accumulation of plant debris in a swamp.

\section{SUMMARY}

An evaluation of the data on the amount and distribution of the 15 minor elements in the coals of this province has led us to the following conclusions:

1. The fusain and vitrain samples of some of the coals of this province have some unusual anomalies. In many cases the fusain contains more of these elements than the vitrain in either the whole block of coal or in any of the petrographic constituents. This is unusual, for in coals from other areas the vitrain contains more of these elements than do fusain or whole blocks of coal. It is possible that this is a secondary accumulation phenomena in the fusains.

2. A graphic plot of the distribution of the elements among blocks of coal of six columnar samples shows a wide range of patterns. In one columnar sample almost all the elements have similar distribution patterns. The other five examples range from nearly similar patterns for most of the elements to almost no similarity between any of the elements. These distributions and the fact that adjacent blocks of coal have large differences in their minor- 
element content suggest that there has been no large-scale secondary redistribution of the elements and that their accumulation in the coal was syngenetic.

3. A comparison of the minor-element content of coal beds at different stratigraphic positions shows no significant pattern of distribution. This lack of a pattern, particularly for the enrichment of the lower beds, bars the possibility of secondary mineralization by hydrothermal solutions. The sampling is too sparse to draw any positive conclusions on this matter.

4. In comparison of a group of beds in a limited area with those of another area some of the elements, such as beryllium, titanium, nickel, cobalt, gallium, yttrium and lanthanum, show a pattern of enrichment or depletion toward some part of the basin. Other elements show no pattern.

5. A comparison of the minor-elements rontent of the coals with that of some plants suggests that the amount of the elements found in the coals could have been accumulated by plants.

6. The minor-element content of the coal from the Fort Union of this province is analagous to the minor-element content of intermediate and silicic rocks. Such rocks were available as a source of sedimentary material during the period of this deposition. This suggests that the minor-element content of coal is controlled by the availability of these elements at the time of deposition of the coal.

7. The minor-element content of the kettle-bottom coals and coalified trees, shows that the stability of metallo-organic complexes and redox potential of the depositional environment, in addition to availability, are important controlling factors in the accumulation or loss of minor elements in these samples and also in coal beds.

In order to assess the validity of the foregoing conclusions, more extensive studies of coal should be made. Complete analyses of the ash, as well as mineralogic studies of the inorganic fractions of the coal, would probably help immeasurably to explain the phenomena that are not understood now.

\section{SELECTED BIBLIOGRAPHY}

Abbolito, Enrico, 1942, Presence of vanadium in the ash of some fossil fuels: Ricera sci., v. 13, p. 563-565 (from Chem. Abs., 1944, v. 38, p. 235).

Asai, Kazuhiko, 1954, Zur Petrographic japanischer Kohlen: Internat. Comm. Coal Petrology Proc., no. 1, p. 51-57.

Asai, Kazuhiko, and Inagaki, Masaru, 1952, Rare elements germanium and gallium in coal: Kagaku no Ryoiki (Jour. of Japanese Chemistry), v. 6, no. 12, p. 724-733. [Translation prepared by Engineer Intelligence Div., Office of Engineer, Headquarters U.S. Army Forces, Far East, Tokyo, Japan, May 1956.] 
Aubrey, K. V., 1952, Germanium in British coals: Fuel, v. 31, p. 429-437.

- 1954, Frequency distribution of the concentration of elements in rocks: Nature [London] v. 174, p. 141-142.

1955, Germanium in some of the waste-products from coal: Nature, v. 176, p. 128-129.

Averitt, Paul 1942, Coal fields of the United States: U.S. Geol. Survey map.

Berryhill, H. L., Brown, D. M., Brown, Andrew, and Taylor, D. A., 1950, Coal resources of Wyoming: U.S. Geol. Survey Circ. 81, 78 p.

Bertetti, Iolanda, 1954, Presence of gallium and germanium in some Italian coals: Accad. ligure sci. e lettere Atti, v. 11, p. 53-58.

Borovik, S. A., and Ratynski, V. M., 1944, Tin in the coals of the Kuznetsk basin: Acad. Sci. U.R.S.S. Comptes rendus, v. 45, p. 120-121.

Brant, R. A., 1953, Lignite resources of North Dakota: U.S. Geol. Survey Circ. 226, $78 \mathrm{p}$.

Breger, I. A., Deul, Maurice, and Meyrowitz, Robert, 1955, Geochemistry and mineralogy of a uraniferous subbituminous coal: Econ. Geology, v. 50, p. 610-624.

Breger, I. A., Deul, Maurice, and Rubinstein, Samuel, 1955, Geochemistry and mineralogy of uraniferous lignite: Econ. Geology, v. 50, p. 206-226.

Breger, I. A., and Schopf, J. M., 1955, Germanium and uranium in coalified wood from Upper Devonian black shale: Geochim. et Cosmochim. Acta, v. 7, p. 287-293.

Brito, Alberto Carlos de, 1955a, Spectrographic study of the ash of Portuguese anthracites: Estudos, notas, e trabalhos serv. fomento mineiro (Portugal), v. 10, p. 236-250 [in Portuguese].

1955b, Spectrographic study of the ash of Portuguese lignite: Estudos, notas, e trabalhos serv. fomento mineiro (Portugal), v. 10, p. 251-262 [in Portuguese].

Butler, J. R., 1953, Geochemical affinities of some coals from Svalbard [Spitsbergen]: Norsk Polarinst., Skr. no. 96, 26 p.

Cannon, H. L., 1955, Geochemical relations of zinc-bearing peat to the Lockport dolomite, Orleans County, New York: U.S. Geol. Survey Bull. 1000-D, p. 109-185.

Combo, J. X., Brown, D. M., Pulver, H. F., and Taylor, D. A., 1949, Coal resources of Montana: U.S. Geol. Survey Circ. 53, 28 p.

Cooke, W. T., 1938, The occurrence of gallium and germanium in some local coal ashes: Royal Soc. South Australia Trans., v. 62, p. 318-319.

Davidson, C. F., and Ponsford, D. R. A., 1954, On the occurrence of uranium in coals: Mining Mag. [London], v. 91, p. 265-273.

Deul, Maurice, and Annell, C. S., 1956, The occurrence of minor elements in the ash of low-rank coal from Texas, Colorado, North Dakota, and South Dakota: U.S. Geol. Survey Bull. 1036-H, p. 155-172.

Dieke, G. H., and Crosswhite, H. M., 1943, The use of iron lines as intensity standards: Optical Soc. America Jour., v. 33, p. 425-434.

Dobbin, C. E., 1930, The Forsyth coal field, Rosebud, Treasure, and Big Horn Counties, Montana: U.S. Geol. Survey Bull. 812, pt. II-A, p. 1-55.

Dono, Tsurumatsu, Yoshida, Takatoshi, Aoki, Minoru, Makagawa, Genkichi, and Iga, Motoichi, 1951, Geochemical investigation of lignite. II. Spectrochemical analysis of lignite: Nagoya Inst. Technol. Bull., v. 3, p. 199-209 (from Chem. Abs., 1954, v. 48, p. 2532).

Eardley, A. J., 1951, Structural geology of North America: New York, Harper and Bros., $624 \mathrm{p}$. 
Fiskel, J. G. A., Mourkides, G. A., and Gammon, Nathan, Jr., 1956, A study of the properties of molybdenum in Everglades peat: Soil Sci. Soc. America Proc., v. 20, p. 73-76.

Fleischer, Michael, 1953, Recent estimates of the abundances of the elements in the earth's crust: U.S. Geol. Survey Circ. 285, 7 p.

Fleischer, Michael, and Harder, J. O., 1946, Geochemistry of germanium: Report to Manhatten Project, 1945, revised as MDDC-645, 1946; 1955, p. 93-105 in Quill, L. L., ed., The chemistry and metallurgy of miscellaneous materials: U.S. Atomic Energy Comm. TID-5212, U.S. Atomic Energy Comm. Tech. Inf. Service, Oak Ridge, Tenn.

Forrest, J. S., Smith, A. C., and Ward, J. M., 1955, Germanium in power station boiler plant: Nature, v. 175, p. 558.

Fortescue, John A. C., 1954, Germanium and other trace elements in some western Canadian coals: Am Mineralogist, v. 39, p. 510-519.

Ganguly, N. C., and Dutta, D. P., 1956, Spectrographic determination of germanium in coals: Jour. Sci. Indus. Research (India), v. 15B, p. 327-328.

Gibson, F. H., and Selvig, W. A., 1944, Rare and uncommon chemical elements in coal: U.S. Bur. Mines Tech. Paper 669, p. 1-23.

Goldschmidt, V. M., 1930, Utber das Vorkommen des Germanium in Steinkohlen und Steinkohlen-Produkten: Gesell. Wiss. Göttingen, Nachr., Mat.-phys. K1., Heft 3, p. 398-401.

-1935, Rare elements in coal ashes: Indus. and Eng. Chemistry, v. 27, p. 1100-1102.

-1954, Geochemistry: London, Oxford Univ. Clarendon Press, 730 p.

Goldschmidt, V. M., and Peters, Cl., 1933, Utber die Anreicherung seltener Elemente in Steinkohlen: Gesell. Wiss. Göttingen, Nachr., Mat.-phys. Kl., Heft 4, p. 371-387.

Hawley, J. E., 1955, Germanium content of some Nova Scotian coals: Econ. Geology, v. 50, p. 517-532.

Headlee, A. J. W., and Hunter, R. G., 1955, Characteristics of minable coals of West Virginia, pt. 5, The inorganic elements in the coals: West Virginia Geol. Survey Bull., v. 13A, p. 36-122.

Hoagland, M. B., 1952, Beryllium and growth. II. The effect of beryllium on plant growth: Archives Biochemistry and Biophysics, v. 35, no. 2., p. 249258.

Horton, L., and Aubrey, K. V., 1950, Distribution of minor elements in three vitrains from the Barnsley seam: Soc. Chem. Industry Jour. [London], v. 69, supp. no. 1, p. s41-s48.

Inagaki, Masaru, 1951, Spectroscopic analysis of inorganic matters in coal, I: Coal Research Inst. Jour. [Japan], v. 2, p. 229-234 (from Chem. Abs., 1955, v. 49 , p. 7221 ).

__ 1952, Germanium in Japanese coals: Coal Research Inst. Jour. [Japan], v. 3, p. 261-267 (from Chem. Abs., 1955, v. 49, p. 7219).

- 1953a, Rare elements in Japanese coal, I. Germanium: Chem. Soc. Japan Jour., Pure Chem. sec., v. 74, p. 19-22 (from Chem. Abs., 1953, v. 47, p. 6631).

1953b, Gallium-a rare element in coal: Coal Research Inst. Jour. [Japan], v. 4, p. 1-6 (from Chem. Abs., 1955, v. 49, p. 7219).

1956, Metallic gallium: Coal Research Inst. Jour. [Japan], v. 7, p. 129-138 (from Chem. Abs., 1956, v. 50, p. 13635). 
Inagaki, Masaru; Oikawa, Hiroshi; Moriya, Shigeo; Yamaguchi, Takuya; and Otsu, Tatsuo, 1954, Germanium in coal. I. Germanium in coal dust and gas liquor: Coal Research Inst. Jour. [Japan], v. 5, p. 359-366 (from Chem. Abs. 1955 , v. 49 , p. 6575).

Itkina, E. S. 1948, Copper in sedimentory rocks of coal deposits of the petroleum region of Ural-Volga: Akad. Nauk SSSR Doklady, v. 62, p. 357-360 (in

Russian).

Iwasaki, Iwaji, and Ukimoto, Isamu, 1942, Coal, I. Rare elements in coal. Vanadium and chromium contents of coal: Chem. Soc. Japan Jour., v. 63, p. 1678-1684 (from Chem. Abs., 1947, v. 41, p. 3408).

Iyer, V. G., and Sundaram, N., 1955, Germanium in coal ash: Indian Mining Jour., v. 3, no. 9, p. 182-183.

Jones, J. H., and Miller, J. M., 1939, The occurrence of titanium and nickel in the ash from some special coals: Chemistry and Industry [London], v. 58, p. 237-245.

Katchenkov, S. M., 1948, Concentration of germanium in coal: Akad. Nauk SSSR Doklady, v. 61, no. 5, p. 857-859 (in Russian).

- 1952, Some general regularities of the accumulation of mineral elements in petroleum and hard coals: Akad. Nauk SSSR Doklady, v. 86, no. 4, p. 805-808 (in Russian).

Knappen, R. S., and Moulton, G. F., 1930, Geology and mineral resources of parts of Corbon, Big Horn, Yellowstone, and Stillwater Counties, Montana: U.S. Geol. Survey Bull. 822-A, p. 1-70.

Kostrikin, V. M., 1939, Germanium in the tar by-products of the coking process: Jour. Appl. Chemistry, U.S.S.R., v. 12, p. 1449-1454 (in Russian).

Kunstmann, F. H., and Hammersma, J. C., 1955, The occurrence of germanium in South African coal and derived products: Chem. Metall. Mining Soc. South Africa Jour., v. 56, no. 1, p. 11-22.

Legraye, Michel, and Coheur, P., 1944-45, Spectrographic study of the coals of the Charleroi basin: Soc. Belgique Geol. Bull., v. 68, p. 63-67 (from Chem. Abs., 1945, v. 39, p. 5067).

Lexow, Siegfried, G., and Maneschi, Ernesto, P. P., 1950, Germanium in Río Turbio coal: Asoc. quim. Argentina Anales, v. 38, p. 225-229 (from Chem. Abs., 1951, v. 45, p. 4020).

Lopez de Azcona, J. M., and Puig, A. C., 1948, The minor elements of the ashes of Asturian coals: Inst. Geol. Min. España Bol., v. 60, p. 391-407 (in Spanish).

Machin, J. S., and Witters, Juanita, 1956, Germanium in fly ash and its spectrochemical determination: Illinois State Geol. Survey Circ. 216, p. 1-13.

Martell, A. E., and Calvin, Melvin, 1952, Chemistry of the metal chelate compounds: New York, Prentice-Hall, Inc., 613 p.

McMannis, W. J., 1957, The Livingston formation, in Billings Geol. Soc. Guidebook 8th Ann. Field Conf., 1957, p. 80-85.

Miropolskii, L. M., 1939, The occurrence of vanadium in the caustobiolites of Tataria: Acad. Sci. U.R.S.S., Bull., Ser. Geol. no. 3, p. 103-110 (English summary).

1942, Distribution of nickel and copper in the caustobiolites of Tataria: Acad. Sci. U.R.S.S. Comptes rendus, v. 35, no. 5, p. 155-156 (in English).

Morgan, Gilbert, and Davies, G. R., 1937, Germanium and gallium in coal ash and flue dust: Chemistry and Industry [London], v. 56, p. 717-721.

Mukherjee, B., 1950, Detection of rare earths in the ashes of Indian coals: Fuel, v. 29 , no. 11, p. 264-266. 


\section{COALS OF NORTHERN GREAT PLAINS COAL PROVINCE A-57}

Mukherjee, B., and Dutta, R., 1948, Spectrographic analysis of Indian coal ash: Sci. and Culture [India], v. 14, p. 213-214.

1949, Germanium in Indian coal ash: Sci. and Culture [India], v. 14, p. $538-539$.

1950, A note on the constituents of the ashes of Indian coals, determined spectroscopically: Fuel, v. 29, no. 8, p. 190-192.

Nazarenko, V. A., 1937, The occurrence of vanadium, beryllium, and boron in the ash of some coals: Acad. Sci. U.R.S.S., Biogeochim. Lab., Trav., v. 4, p. 265-270 (from Chem. Abs., 1938, v. 32, p. 7770).

Newmarch, C. B., 1953, Geology of the Crowsnest basin, with special reference to the Fernie area: British Columbia Dept. Mines Bull. no. 33, $107 \mathrm{p}$.

Oka, Yoshinaga; Kanno, Takuji; Ayusawa, Saburo; and Haga, Kazuo, 1955, Rare elements in bituminous coal and lignite. I. Germanium in lignites from North Miyagi and South Iwate prefectural areas: Bull. Research Inst. Mineral Dressing and Metallurgy, Tohoku Univ., v. 11, p. 17-28 (from Chem. Abs., 1955, v. 49, p. 15209).

Ono, Kenji; Inada, Yoichi; and Kanno, Ikuo, 1955, Utilization of lignite containing germanium: Bull. Research Inst. Mineral Dressing and Metallurgy, Tohoku Univ., v. 11, p. 159-164 (from Chem. Abs., 1956, v. 50, p. 13405).

Otte, M. U., 1953, Trace elements in some German mineral coals: Chemie der Erde, v. 16, p. 237-294 (in German).

Pitt, G. J., and Fletcher, M. F., 1955, The spectrographic determination of germanium in coal and flue dust: Spectrochim. Acta, v. 7, p. 214-218.

Powell, A. R., Lever, F. M., and Walpole, R. E., 1951, Extraction and refining of germanium and gallium: Jour. Appl. Chemistry, v. 1, p. 541-551.

Rafter, T. A., 1945, Boron and strontium in New Zealand coal ashes: Nature, v. 155, p. 332 .

Rankama, Kalervo, and Sahama, Th. G., 1950, Geochemistry: Chicago, Univ. of Chicago Press, $911 \mathrm{p}$.

Ratynskii, V. M., 1945, Sur la génèse du germanium dans l'houille: Acad. Sci. U.R.S.S. Comptes rendus, v. 49, p. 119-122.

1946, Germanium in coal: Akad. Nauk SSSR Biogeokhim. Lab. Trudy, v. 8, p. 183-223 (from Chem. Abs., 1953, v. 47, p. 7961).

Reynolds, F. M., 1948, The occurrence of vanadium, chromium and other unusual elements in certain coals: Soc. Chem. Industry Jour. [London], v. 67, p. 341-345.

- 1950, Gallium and germanium extraction from flue dust: Chem. Products, v. 13, p. 152-153.

Robinson, W. O., Bastron, Harry, and Murata, K. J., 1958, Biogeochemistry of the rare-earth elements with particular reference to hickory trees: Geochim. et Cosmochim. Acta, v. 14, p. 55-67.

Robinson, W. O., and Edgington, Glen, 1945, Minor elements in plants and some accumulator plants, p. 15-28, in Bear, F. E., and Kitchen, H. B., eds., Minor elements: Baltimore, Maryland, The Williams and Wilkins Co.

Salmi, Martti, 1950, Trace elements in peat: Geol. tutkimuslaitos, Geotek. julkaisuja, v. 51, p. 1-20 (English summary).

1954, A peat chemical prospecting method: Geologi [Finland], v. 6, p. 69-70 (in Finnish).

1955, Prospecting for bog-covered ore by means of peat investigations: Comm. Geol. Finlande Bull. 169, p. 1-34 (in English).

Sandell, E. B., and Goldich, S. S., 1943, The rarer metallic constituents of some American igneous rocks: Jour. Geology, v. 51, no. 2. p. 99-115. 
Schleicher, J. A., and Hambleton, W. W., 1954, Spectrographic investigation of germanium in Kansas coal: Kansas Geol. Survey Bull. 109, p. 113-124.

Shakhov, F. N., and Efendi, M. E., 1946, The geochemistry of the coals of the Kuznetsk basin: Acad. Sci. U.R.S.S. Comptes rendus, v. 51, p. 139-140 (in English).

Simek, B. G., 1940, The germanium content of coals of the Ostrau-Karwin basin: Chem. Listy, v. 34, p. 181-185 (from Chem. Abs., 1943, v. 37, p. 4036).

Simpson, A., 1954, The Nigerian coal field; the geology of parts of Onitsha, Owerri, and Benue provinces: Nigeria Geol. Survey Bull. 24, $67 \mathrm{p}$.

Stadnichenko, Taisia, Murata, K. J., and Axelrod, J. M., 1950, Germaniferous lignite from District of Columbia and vicinity: Science, new ser., 112, p. 109.

Stadnichenko, Taisia, Murata, K. J., Zubovic, Peter, and Hufschmidt, E. L., 1953, Concentration of germanium in the ash of American coals, a progress report: U.S. Geol. Survey Circ. 272, 34 p.

Stadnichenko, Taisia, Zubovic, Peter, and Sheffey, Nola B., 1961, Beryllium content of American coals: U.S. Geol. Survey Bull. 1084.

[Stose, G. W. and Ljungstedt, O. A.], 1932, Geologic map of the United States: U.S. Geol. Survey.

Stow, M. H., 1946, Dating sedimentation, vulcanism, and orogeny in Beartooth Mountain region, Montana, by heavy minerals: Geol. Soc. American Bull., v. 57 , no. 7 , p. $675-686$.

Subrahmanyan, S., and Nair, A. P. M., 1955, Germanium in South Arcot lignite: Jour. Sci. Indus. Research [India], v. 14B, p. 606 (from Chem. Abs., 1956, v. 50, p. 6018).

Vickery, R. C., 1953, Chemistry of the lanthanons: New York, Academic Press, Inc., $296 \mathrm{p}$.

Vinogradov, A. P., 1956, The regularity of distribution of chemical elements in the earth's crust: Akad. Nauk SSSR Geokhim., v. 1, p. 1-52. Translated by Botcharsky, S., 1957, Atomic Energy Research Establishment AERELib/Trans-795, Harwell, England.

Warren, H. V., and Delavault, R. E., 1954, Variations in the nickel content of some Canadian trees: Royal Soc. Canada Trans., v. 48, ser. 3, sec. 4, p. 71-74.

Warren, H. V., Delavault, R. E., and Irish, Ruth I., 1951, Further biogeochemical data from the San Manuel copper deposit, Pinal County, Arizona: Geol. Soc. America Bull., v. 62, no. 8, p. 919-930.

Warren, H. V., Delavault, R. E., and Routley, D. G., 1953, Preliminary studies of the biogeochemistry of molybdenum: Royal Soc. Canada Trans., v. 47, ser. 3 , sec. 4 , p. 71-75.

Wilsor, S. H., and Rothbaum, H. P., 1950, Spectrographic determination of gallium and germanium in ash of New Zealand coals: New Zealand Dept. Sci. Indus. Research, Coal Research Comm., Rept. no. 248, p. 1-6.

Woolsey, L. H., Richards, R. W., and Lupton, C. T., 1917, The Bull Mountain coal field, Musselshell and Yellowstone Counties, Montana: U.S. Geol. Survey Bull. 647, 218 p.

Zilbermintz, V. A., 1935, Occurrence of vanadium in fossil coals: Acad. Sci. U.R.S.S. Comptes rendus, v. 3, p. 117-120 (in English).

1936, Germanium content in the Donets basin coals: Mineral. Syrie no. 11, p. 16-26 (from Chem. Abs., 1936, v. 30, p. 7306).

Zilbermintz, V. A., and Rusanov, A. K., 1936, The occurrence of beryllium in fossil coals: Acad. Sci. U.R.S.S. Comptes rendus, v. 2, no. 1, p. 27-31 (in English). 

